\title{
Akış Deneyiminin Mobil Oyun Bağımlılığı ve Keşifsel Davranış Üzerindeki Etkisi: Ağızdan Ağıza Pazarlama Kapsamında Bir İncelenme ${ }^{1}$
}

\author{
Fatih ŞAHIN ${ }^{2}$ ve Mehmet Ozan KARAHAN ${ }^{3}$
}

\section{$\ddot{O}_{z}$}

Araştırmanın temel amacı Akıs Teorisi (Flow Theory) unsurlarından olan eğlence, tele varoluş, konsantrasyon ve zaman algısında bozulma faktörlerinin, tüketicilerin mobil oyun bağımlılıkları ve keşifsel davranışları üzerindeki etkilerinin belirlenmesi ve aynı şekilde tüketicilerin mobil oyun bağımlılıkları ve keşifsel davranışlarının pozitif ve negatif ağızdan ağıza pazarlama (WOM) üzerindeki etkilerinin değerlendirilmesidir. Araştırmanın ana kütlesini Uşak Üniversitesi'ndeki 18 yaşından büyük mobil oyunları oynayan bireyler oluşturmaktadır. Çevrim içi anket formu kullanılarak 407 geçerli veriye ulaşılmış ve yapısal eşitlik modellemesi kullanılarak analiz edilmiştir. Araştırma bulgularına göre, akış teorisinin tüm unsurlarının (konsantrasyon, eğlence, zaman algısında bozulma ve tele varoluş) bireylerin mobil oyun bağımlılıkları üzerinde anlamlı etkilere sahip olduğu görülürken, yine tele varoluş hariç bu unsurların keşifsel davranışlar üzerinde de anlamlı etkilerinin olduğu gözlemlenmektedir. Son olarak, keşifsel davranışın aksine; mobil oyun bağımlılı̆̆ının olumlu WOM ve olumsuz WOM faktörleri üzerindeki etkisinin anlamlı olduğu tespit edilmiştir. Araştırma sonuçlarına göre eğlence, tele varoluş, konsantrasyon ve zaman algisı gibi akış deneyimi faktörleri göz önüne alınarak oyun ve oyunlaştırma uygulamaları optimum şekilde tasarlanmalıdır.

Anabtar Kelimeler: Akış Teorisi, Mobil Oyun Bağımlılığı, Keşifsel Davranış, Olumlu WOM, Olumsuz WOM

The Effect of Flow Experience on Mobile Game Addiction and Exploratory Behavior: A Study in the Context of Word-of-Mouth Marketing

\begin{abstract}
This study aims to examine the effects of enjoyment, telepresence, concentration, and time distortion factors which are flow experience elements on the mobile game addiction and exploratory behaviors of consumers, and to analyze the effects of mobile game addictions and exploratory behaviors of consumers on WOM (word-of-mouth, positive and negative valences). The participants of this study were chosen from people who play mobile games regularly and older than 18 years in Uşak University. Online questionnaires form link shared with participants and a total of 407 valid data collected, in the analysis of the research model structural equation modeling was employed by using SPSS and Amos software. The antecedents of flow theory (enjoyment, telepresence, concentration and time distortion) in the scope of this research have found that significant effects on the mobile game addiction and exploratory behavior of individuals except for telepresence. However, contrary to exploratory behavior, in the scope of research findings reached the conclusion concluded that mobile game addiction has an effect on positive and negative WOM was significant. Research results indicate that games and gamification applications should be designed in an optimum way, taking into account the flow experience factors such as entertainment, telepresence, concentration, and time perception.
\end{abstract}

Key Words: Flow Theory, Mobile Game Addiction, Exploratory Behavior, Positive WOM, Negative WOM

\section{Atıf İçin / Please Cite As:}

Şahin, F. ve Karahan, M. O. (2021). Akış deneyiminin mobil oyun bağımlılığı ve keşifsel davranış üzerindeki etkisi: Ağızdan ağıza pazarlama kapsamında bir incelenme. Manas Sosyal Araştırmalar Dergisi, 10(2), 1314-1331.

Geliş Tarihi / Received Date: 08.01.2021

Kabul Tarihi / Accepted Date: 20.02.2021

\footnotetext{
${ }^{1} \mathrm{Bu}$ araştırmada kullanılan veri ile araştırmada uygulanacak yöntemler Uşak Üniversitesi Sosyal ve Beşerî Bilimler Bilimsel Araştırma ve Yayın Etiği Kurulunun 13.04.2020 tarih ve E12886 sayılı yazısı ile uygun bulunmuștur.

${ }^{2}$ Dr. Öğr. Üyesi - Bandırma Onyedi Eylül Üniversitesi, Gönen Meslek Yüksekokulu, fsahin@bandirma.edu.tr

(iD) ORCID: 0000-0002-4760-4413

3 Öğr. Gör. Dr. - Uşak Üniversitesi, Eşme Meslek Yüksekokulu, mozan@usak.edu.tr

(iD ORCID: 0000-0001-7287-5904
} 


\section{Giriş}

Oyun oynamak günümüzde internet kullanıcıları arasında en popüler etkinlikler arasında yer almaya başlamış ve bu eğilim küresel kapsamda da artış göstermektedir (Lenhart, Kahne, Middaugh, Macgill, Evans, 2008, s. 16). Buna bağlı olarak genel ekonomi içerisinde oyun sektörünün rolünün daha fazla önem kazanmaya başladığı anlaşılmaktadır (Zhu ve Zhang, 2010, s. 138; Landsman ve Stremersch, 2011, s. 40). Bu kapsamda Türkiye'deki oyun sektörü gelir açısından değerlendirildiğinde, 2017 yllında oyun sektörünün elde ettiği gelir toplam 332 milyon Amerikan doları iken bu rakam 2020 yllında 401 milyon Amerikan dolarına yükselmiştir. Dünya genelinde oyun sektörünün toplam gelirinin ise 2021 yllında 11,94 milyar Amerikan dolarına ulaşacağı tahmin edilmektedir (Statista, 2020a). Oyun sektöründeki değişimi bir başka açıdan değerlendirmek amacıyla çeşitli yaş gruplarının oyunlara yönelik eğilimlerini ve birçok bağlamda oyunların artan etkisini incelemek gerekmektedir. Türkiye'deki oyuncular yaş grupları açısından incelendiğinde, oyuncuların ortalama yaşının 35 olduğu ve bu oyuncuların \%35'inin 25-34 yaş aralığında, \%28,6'sının 35-44 yaş aralığında, 45 ve üzeri yaş grubunda bulunan oyuncuların oranın ise \%11,6 olduğu anlaşılmaktadır (Statista, 2019). Türkiye'deki oyuncuların \%57,2'sinin erkek, \%42,8’i ise kadın oyunculardan oluşmaktadır. Oyuncuların gelir durumları değerlendirildiğinde ise \%44'ünün düşük düzey, $\% 25$ 'inin orta düzey ve \%30'unun ise üst düzey gelir grubundan oluştuğu anlaşılmaktadır (Statista, 2020b). Oyun oynama alışkanlıkları kullanıcıların tercih ettikleri cihaz açısından incelendiğinde, $\% 75$ akıllı telefon, $\% 59$ bilgisayar, $\% 35$ tablet, $\% 23$ oyun konsollar1 ve $\% 22$ oranında ak1llı televizyonlar tercih edilmektedir (Statista, 2020c). Kullanıcıların oyun oynarken akıllı telefonları tercih etmeleri mobil oyun oynayıcilarının sayısının da diğer oyun platformlarına oranla daha fazla olduğunu ortaya koymaktadır. Bununla birlikte, Türkiye'deki mobil oyuncularnnın tek bir oyunla yetinmediği, ortalama olarak en az dört oyuna sahip oldukları değerlendirilmektedir.

Pazarlama, her zaman içinde bulunduğu çevresel faktörlere bağlı kalarak tüketicilerin dünyasına uyum sağlamaya çalışmış ve hatta ona yön verebilmeyi başarabilmiştir. Her teknolojik, kültürel, sosyal değişim pazarlamaya yönelik alg1yı değiştirmiş ve yatırım getirisini arttırabilmek için pazarlamacıları yeni alanları keşfetmeye zorlamıştır. Modern pazarlama kapsamında denenmiş ve kanıtlanmış metotların yanı sıra, yeni akımların yönlendirdiği başarılı olmuş stratejiler ve moda olan kavramların çerçevesinde deneme yanılma yöntemiyle gerçekleştirilen uygulamalara da tanıklık etmekteyiz. Günümüzde genel olarak oyun oynama faaliyetlerin de artış gözlendiği gibi küresel kültürün de önemli bir parçası haline gelmeye başlamıştır (Consalvo, 2006, s. 126). Bu kapsamda, insanların genel olarak oyunlara yönelik geçmişten gelen ilgisinin, günümüz teknolojik gelişimi ile video oyunlara yönelik değişim göstermesi sonucu 2010 yllında pazarlamanın oyunlaştırma uygulamalarına yöneldiğine tanık olmaktayız. Bu ilgi, ilk başlarda gelip geçici moda bir kavram olarak görülse de etkinliğini korumayı başarabilmiştir. Teknolojik gelişmeler bireylere internetten, sosyal medyaya ve çeşitli dijital uygulamalara erişebilecekleri birden fazla cihaza sahip olma imkânı tanıması, bireylerin oyunlara yönelik ilgilerinin artış eğiliminde devamlılı̆̆a katkı sağlamaktadır. İşletmeler tarafından oyunlaştırma faaliyetleri bireylerin sahip oldukları bu cihazların her birine yönelik ayrı uygulamalarla ya da bu cihazlar arasında eş güdümlü olarak da yürütülebilmektedir. Günümüzde oyunlar mobil telefon, tablet, dizüstü bilgisayar, masaüstü bilgisayar ve hatta akıllı televizyonlar gibi farklı platformların her biri için uygulanabilir hale gelmiş ve bu durum oyunlaştırma uygulamaları kullanılarak gerçekleştirilen faaliyetlerin sınırsız bir alanda uygulanabilmesini mümkün hale getirmiştir. Özellikle, demografik faktörler açısından birbirinden farklı özelliklere sahip oyuncuların olması, oyunların etki alanını da artırmaktadır. Bu sebeple, oyun ve oyunlaştırma işletmelerin hedeflerine ulaşabilmesinde stratejik bir araç olarak ele alınmaktadır. Bu alanda gerçekleştirilen araştırmalara göre, işletmeler açısından oyunlaştırma uygulamaları aracılığı ile gerçekleştirilen pazarlama faaliyetlerinin diğer geleneksel ve dijital platformlara kıyasla daha etkin olduğunu gösteren sonuçlara ulaşmışlardır (Conaway ve Garay, 2014; Hofacker, De Ruyter, Lurie, Manchanda ve Donaldson, 2016; Huotari ve Hamari, 2017). Oyunlaştırma uygulamalarının kitlesel olarak tasarlanabilmesi birçok pazarlama firsatını da beraberinde getirmektedir. İşletmelerin doğrudan hedef kitle ile etkileşime geçebilmesi, marka ile ilgili yönetilen herhangi bir soruya veya paylaşıma yönelik cevap verebilme imkânın olması, pazarlama stratejisi çerçevesinde kullanıcılar için oluşturulan yeni görevler ve ödüllerin duyurulması, hedef kitle ile olan etkileşimi daha eğlenceli ve etkili hale getirebilmektedir. Oyun içerisinde verilen görevlerin tamamlanması, yarışmalar ve benzeri etkinliklerde oyun sıralamasına giren tüketicilerin ödüllendirilmesi ve takdir edilmesi, hedef kitlenin rekabet ve heyecan duygusunu deneyimleyebilmeleri gibi birçok faaliyetin gerçekleştirilebilmesini de sağlayabilmektedir. $\mathrm{Bu}$ gibi ilgi çekici faaliyetler tüketicilerin yakın çevresindeki arkadaşlarını sosyal medya hesaplarında etiketlemelerini, kendi istekleri ile sosyal medya hesaplarından duyurmalarını mümkün kılmaktadır. 
Günümüzde tüketicilerin tanıdıkları ve güvendikleri markalar ile iş birliği içerisinde olmak istedikleri değerlendirildiğinde pazarlama açısından oyunlaştırma önemli firsatlar sunmakta ve rekabet avantajı sağlayabilmektedir.

Diğer taraftan, çevrim içi oyunların büyük bir sektör haline gelmesi ve popülaritesinin artması, çözülmesi gereken bazı sorunları da beraberinde getirmektedir. Özellikle oyunların yaşam döngüsünün kısalması, oyun geliştiricilerinin çözmesi gereken bir sorun haline gelmiştir (Huang, Ali ve Liao, 2017, s. 329). Bu sorunu çözebilmek amacıyla oyun geliştiricileri ve oyunlaştırma uygulamalarını kullanan işletmeler hedef pazardaki ürünleri daha ilgi çekici hale getirebilmek ve böylelikle ağızdan ağıza pazarlama stratejisinin gücünden faydalanarak (Godes ve Mayzlin, 2004, s. 558; Cheung ve Thadani, 2012, s. 461) oyunların yayılma hızlarını artırmaya çaba göstermektedirler. İşletmelerin müssteriler ile olan iletişim çabalarının etkinliğinin arttırlması ve karşılaşılan iletişim sorunlarının çözümünde oyunlaştırma uygulamaları ile güdülenen ağızdan ağıza pazarlama uygulamaları önemli bir yere sahiptir (Shin, Chae, ve Ko, 2018, s. 73). Fakat diğer taraftan çevrim içi oyunlarda ağızdan ağıza pazarlama niyetini etkileyen faktörlerin neler olduğuna yönelik bu alandaki çalışmaların kısıtlı olduğu anlaşılmaktadır (Huang vd., 2017, s. 329). Kullanıcı ve oyun arasındaki etkileşimin doğasından kaynaklı olarak, oyunların yaşam döngüsünün kısa olması ve nasıl hızlı şekilde yayılıp benimsenebilmesinin sağlanabileceği gibi sorunların yanı sıra araştırılması gereken başka konular da bulunmaktadır. Özellikle kullanıcıların deneyimledikleri optimum akış deneyimi bazı avantajlar sunduğu gibi dezavantajları da beraberinde getirebilmektedir. Bu alanda ilgili gören konulardan bir tanesi de akış deneyiminin, çevrim içi oyunlara yönelik bağımlılı̆̆a neden olup olmadığıdır. Her ne kadar bu alandaki çalışmalar tam olarak aradaki ilişkiyi net olarak ortaya koyamasalar da bazı araştırmalar bu iki değişken arasında doğru yönlü bir ilişkinin varllğını savunurken (Chou ve Ting, 2003; Seah ve Cairns, 2008; Wu, Scott, ve Yang, 2013), bazı araştırmalar ise bu ilişkinin ters yönlü olduğunu (Wan ve Chiou, 2006; Wood ve Griffiths, 2007; Weibel, Wissmath, Habegger, Steiner, ve Groner, 2008) öne sürmektedir. İnternet kullanımı (Young, 1998) ve çevrim içi oyunların (Kuss ve Griffiths, 2012) bireyler arasında popülerliğinin artmasının psikolojik olarak bağlllı̆ga ve bağımlılığa yol açtığ düşünülmektedir. Lin, Hung, Fang, ve Tu (2015, s. 844)'ya göre çevrim içi oyunlar internet üzerinde en fazla bağımlilığa neden olan faaliyetler arasındadır. İnternet bağımlılığ açısından konuyu ele alan Kardefelt (2014, s. 351), internet bağımlılığını bireyin internet kullanımına yönelik kontrolü kaybetmesi ile başlayarak, yaşamını olumsuz yönde etkileyecek bazı çıktılara neden olana kadar bireyin internet kullanımına devam etme durumu olarak ifade etmektedir. Özellikle bağımllık seviyesinin fazla olduğu durumlarda, oyun bağımlılı̆ının bireyin uykularını kaçırmasına, yemek öğünlerini atlamasına, aile bireyleri ile çatışmasına ve kariyerinde geri kalmasına neden olabilmektedir (Young, 1998, s. 241). Psikoloji ve bağımlılık alanında gerçekleştirilen araştırmalara göre sorunlu sosyal medya kullanımının artış nedenlerinden (Kurcaburun, Demetrovics ve Tosuntaş, 2019, s. 1504) birisinin internet bağımlilığ1 (Young, 1998, s. 240) olduğu belirlenmiştir. Bu alanda gerçekleştirilen bir araştırmaya göre, çevrim içi oyunları yoğun bir şekilde kullananların, uyuşturucu, kumar, internet ve benzeri bağımlılık davranışına sahip bireylere benzer bir davranış sergilediğini öne sürmektedir (Shaffer, LaPlante, LaBrie, Kidman ve Donato, 2004, s. 367; Kuss ve Griffiths, 2012, s. 290). Çevrim içi oyunlar alanında gerçekleştirilen bir diğer araştırmaya göre uzman oyuncuların deneyimsiz oyunculara göre akış deneyiminden zevk alma ve oyun bağımlılığı belirtileri gösterme olasilığının daha yüksek olabileceğini öne sürmektedir (Wu vd., 2013). Bu bağımlılık davranışları zaman zaman bazı önemli sosyal ve davranışsal sorunlara yol açabilmektedir (Kuss vd., 2014, s. 21). Çevrim içi oyun bağımlılığın en çok görünen çıktıları arasında depresyon, düşmanlık ve siber zorbalık gibi agresif davranışlar da yer alabilmektedir (Chang, Chiu, Miao, Chen ve Lee, 2015, s. 27). Israeli, Lee ve Bolden (2019a, s. 155) tarafindan gerçekleştirilen bir araştırmaya göre, internet bağımlılı̆̆ saldırgan müşteri davranışlarına neden olmakta bu ise ağızdan ağıza pazarlama faaliyetlerine yansiyabilmektedir. Diğer taraftan bağımlı bireyler, hizmet hatalarından kaynaklı sonuçlarla karşılaştıklarında ağızdan ağıza pazarlama faaliyetlerinde kötü söz kullanıma eğilimi göstermektedirler (Israeli, Lee ve Karpinski, 2019b, s. 958). Genel olarak internet bağımlılı̆g1 (Ko, Yen, Yen, Chen ve Chen, 2012) ve çevrim içi oyun bağımlılı̆̆ (Kim, Namkoong, Ku ve Kim, 2008) alanlarında araştırmaların kısıtlı olduğu da anlaşılmaktadır.

Bu kapsamda bu araştırmanın bazı amaçları bulunmaktadır. İlk olarak araştırma kapsamında bireylerin akış deneyimini etkileyen her bir faktör bağımlılık ve keşifsel kullanıcı davranışları açsından incelenmesi planlanmaktadır. Bu aşamada, hangi akış deneyimi bileşeninin (eğlence, tele varoluş, konsantrasyon ve zaman algısında bozulma) patolojik (bağımlılık) ve patolojik olmayan (keşifsel) davranış üzerindeki etkilerinin bulunup bulunmadığı değerlendirilecektir. Araştırmanın ikinci amacı ise bağımlılık ve keşifsel davranışların olumlu ve olumsuz ağızdan ağıza pazarlama faaliyetleri üzerindeki etkisi incelenmeye 
çalışlacaktır. Elde edilecek olan araştırma sonuçlarının özellikle oyun geliştiricileri ve oyunlaştırma uygulamalarını kullanan işletme yöneticilerine, kullanıcı ve de müşteri davranışları hakkında bazı önemli bilgiler sağlayacağı ve aynı zamanda ilgili yazına katkı sağlayacağı düşünülmektedir.

\section{Literatür}

Akış deneyimi, bir bireyin belirli bir faaliyete yönelik olarak, kendisini tamamıla faaliyete vermesi böylelikle söz konusu deneyimin olağan bir hale dönüşmesi hissi olarak tanımlanmaktadır (Csikszentmihalyi, 1975). Akış deneyimi ile ilgili gerçekleştirilen ilk araştırmalar arasında sayılan bu çalışmaya göre, bireyler akışı deneyimlediklerinde gerçekleştirdikleri faaliyetlere kendilerini kaptırmakta ve bunun neticesinde deneyimi olağan karşılamaya başlamaktadırlar. Tanım çerçevesinde akış deneyimi, gerçekleştirilen belirli bir faaliyet sonrası oluşan duyarllı1k ile başa çıkma stratejisinden daha çok, belirli bir faaliyetin gerçekleşme süreci içerisindeki duygu durum olarak değerlendirilmektedir. Csikszentmihalyi (1975) tarafindan öne sürülen akış deneyimi bireylerin spor, iş, alısveriş, oyun, hobi ve bilgisayar kullanımı gibi faaliyetler ile uğraşırken ortaya çıkan, kendine özgü psikolojik bir olgu olarak ele alınmaktadır. Bununla birlikte zihinsel ve bedensel faaliyetlerde de akışın deneyimlenebileceği savunulmaktadır (Csikszentmihalyi, 1990, s. 94-117). Akış deneyimi, optimum deneyim veya bölgede olmak (akış deneyimi) olarak da nitelendirilmektedir (Chen, 2007, s. 32). Akış deneyimi ile ilgili literatür incelendiğinde, akış elektronik ticaret uygulamalarına (Jiang ve Benbasat, 2004), çevrim içi mağazalara (Koufaris, 2002), mobil televizyon uygulamalarına (Zhou, 2013), öğrenme performansının arttırılmasına (Yen ve Lin, 2020) ve çevrim içi oyunlara (Kim, Oh ve Lee, 2005; Lee, 2009; Liu, 2017) yönelik istenilen davranışın geliştirilmesini sağlayan optimal deneyim olarak tanımlanmaktadır.

Akış deneyiminin ölçülmesine yönelik literatürde farklı uygulamalar bulunduğu görülmektedir. Bir araştırmada (Novak, Hoffman ve Yung, 2000), akış deneyimi tek boyutlu bir model kullanılarak yetenek/kontrol, zorluk/uyarılma ve tele varoluş/zaman algisında bozulma ögeleri ile ölçülmüştür. Koufaris (2002) ve Zhou (2013) akış deneyimini eğlence, konsantrasyon ve algılanan kontrol boyutlarını kullanarak çok boyutlu bir modelle ölçümlemişlerdir. Hausman ve Siekpe (2008) akış deneyiminin ölçümüne yönelik olarak eğlence, konsantrasyon, kontrol ve zorluk boyutlarını kullanmıştır. Akış deneyiminin öncüllerinin incelendiği bir araştırmada (Guo ve Poole, 2009), konsantrasyon, kontrol hissi ve zaman algısında değişme boyutları kullanılmıştır. Lee ve Chen (2010) çevrim içi tüketici davranışlarında akış deneyiminin etkisini incelemek üzere, eğlence, konsantrasyon, tele varoluş ve zaman algısında bozulma boyutlarını kullanmışlardır. Bu alanda gerçekleştirilen araştırmalar sonucunda akış deneyiminin ölçümüne yönelik eğlence, konsantrasyon, tele varoluş ve zaman algisında bozulma değişkenlerinin sıklıkla kullanıldığı anlaşılmaktadır (Hoffman ve Novak, 2009; Lee ve Chen, 2010; Zhou, 2013; Esteban, Martínez, Huertas, Meseguer ve Rodríguez, 2014; Yang, Lu, Wang ve Zhao, 2014). Bu ulaşılan sonuçlar doğrultusunda bu araştırmada da akış deneyiminin ölçümüne yönelik olarak eğlence, konsantrasyon, tele varoluş ve zaman algısında bozulma değişkenleri kullanılacaktır.

Akış durumu, çevrim içi oyun kullanıcılarının bu yöndeki faaliyetlere devam etme niyetlerini ve tekrarlama gücünü ölçmek amaciyla da kullanılmaktadır (Kim vd., 2005, s. 78). Bunun nedenin ise akış deneyiminin kullanıcıların oyuna bilişsel olarak daldıklarında, zaman ve diğer ilgi alanlarının yanı sıra dış baskilardan da siyrilabilmelerini sağlayan bir deneyim olmasından kaynaklanmaktadır (Chen, 2007, s. 32). Kullanıcılar video oyunlarının bu akışı sağlayıp sağlamadıklarını göz önünde bulundurarak değer yükleyebilmektedirler. Böylelikle akışı deneyimleyen bir birey daha önce gerçekleştirmiş olduğu faaliyeti tekrarlama eğilimi gösterebilmektedir (Csikszentmihalyi, 1975). Bu açıdan akış deneyimi, çevrim içi oyunlara yönelik istenilen davranışın geliştirilmesini sağlayan optimal deneyim olarak tanımlanmaktadır (Kim vd., 2005; Lee, 2009; Liu, 2017). Akış deneyiminin belirli bir bilgi teknolojisine yönelik istenilen davranışların sergilenmesine neden olduğu için olumlu çıktılar sağladığı da düşünülmektedir. Akış kavramının daha iyi anlaşılabilmesini sağlamak amacıyla Hoffman ve Novak (1996, s. 59), akış deneyimi ile ilişkili öncül ve ardıl değişkenlerin yer aldığı bütünleşik bir model öne sürmektedir. Bu modelde akış durumunun anlık sonuçları beş bölümde ele alınabilmektedir. Bu bölümler; tüketici öğrenmesi, algılanan davranışsal kontrol (kendine güven), keşifsel davranış, olumlu sübjektif deneyim (mutluluk, vb.) ve zaman algısında bozulma olarak sıralanmaktadır. Bununla birlikte akış deneyimi her zaman arzu edilen olumlu bir sonuç ile neticelenmeyebilmektedir. Bu alanda gerçekleştirilen bazı araştırmalar ise teknolojinin sağlıksız ve bir şekilde aşırı kullanımının, sorunlu olabileceğini ve olumsuz sonuçlara neden olabileceğini ortaya koymaktadir (Chou ve Ting, 2003; Wan ve Chiou, 2006; Turel, Serenko ve Giles, 2011; Yang vd., 2014). Bu konu bu araştırmada oyun bağımlllığ kapsamında ele alınmaktadır. 


\section{Akış Deneyimi ve Keşifsel Davranış}

Keşifsel davranış, bir bireyin kendi davranışı ile yeni bir duruma maruz kalmasını belirlemesi, bunu yaparken de uyarıcıların miktarını ve süresini kendisinin belirlemesini ifade etmektedir (File, 1985, s. 45). Başka bir yaklaşıma göre keşfedici davranış, çevre hakkında bilgi edinmeye yönelik davranışlarda artışa neden olmaktadır (Meyer, 1998, s. 403). Bu nedenle keşifsel davranış, akış durumu içerisindeki bir bireyin bir faaliyete yönelik olan ilgisinin artması olarak da ifade edilebilmektedir (Novak vd., 2000, s. 34; Zaman, Anandarajan ve Dai, 2010, s. 1016). Bir birey bir aktiviteden zevk alırken, can sıkıntısı veya kaygı gibi diğer duygulara kapılması durumunda akışın tekrar sağlanabilmek ve devamlılığını sağlamak amaciyla gerçekleştirdiği aktivitenin farklı yönlerini keşfetme ihtiyacı duymaya başlar (Csikszentmihalyi, 2008, s. 74). Koufaris $(2002$, s. 213) tarafindan bu kapsamda gerçekleştirilen araştırmada, çevrim içi alışveriş yapan müşterilerin satın alma faaliyetlerinin aslında keyif aldıkları internet sayfalarını keşfetme ihtiyacından kaynaklandığını ortaya koymaktadır. Diğer araștırmalarda da (Webster, Trevino ve Ryan, 1993; Ghani ve Deshpande, 1994; Hoffman ve Novak, 1996; Novak vd., 2000) bilgisayar teknolojilerine yönelik akış deneyimlerinin keşifsel davranışla ilişkili olduğu sonucuna ulaşılmıştır.

Ghani ve Deshpande'ye göre (1994, s. 387) konsantrasyon ve eğlence optimal akış deneyiminin iki temel bileşendir. Eğlence değisskeni mutlak konsantrasyonun artık ürünü olarak değerlendirmektedir. Bu iki bileşenin ortak noktası, belirli bir eylemin gerçekleştirilmesi esnasında zaman algısının kaybolmasına neden olmalarıdır. Bu sebeple optimal deneyim sürecin sonunda değil süreç içerisinde güçlü bir şekilde deneyimlenebilmektedir. Akış deneyimi, eğlence ve keşifsel bir yapıya sahip olmasının yanı sıra aynı zamanda oldukça öznel bir kişisel deneyimdir (Webster vd., 1993, s. 412). Özellikle keyif verici obje ile etkileşim esnasında çok güçlü bir ilgilenme ve eğlence hissi gelişmesi daha sonraki zamanlarda keşifsel davranışlarda artışa neden olabilmektedir. Hoffman ve Novak (1996, s. 59) ve Novak vd. (2000, s. 24) çalışmalarında akış durumunun öne çıkan temel özelliklerini, üst düzey beceri ve kontrol, yüksek düzeyde zorluk ve uyarılma, odaklanmış dikkat (konsantrasyon), içsel zevk ile bunların etkileşimi ve tele varoluş ile güçlendirilmesi şeklinde tanımlamaktadırlar. Akış durumu içerisinde tüketici kendine güven ve keşifsel arzu ile mutluluk hissini deneyimleyebilmekte ve böylelikle tüketicinin öğrenme süreci kolaylaştırılmaktadır. Ayrıca, Hauser, Urban ve Weinberg (1993, s. 456) bireylerin zaman baskısı altında bulunduğunda olumsuz bilgi kaynaklarına yönelik arayışa yönelik ayırdıkları zamanı artırmakta, zaman baskısının ortadan kalması sonucu ise olumlu bilgi kaynaklarını aramaya yönelik ayırdıkları süreyi arttırdıklarını bir model çerçevesinde açıklamışlardır. Bu açıdan değerlendirildiğinde, akış durumundaki bireyler zaman baskısını azalttığı ve ilgili faaliyete yönelik harcadığı süreyi arttırabildiği ölçüde, olumlu bilgi kaynaklarına yönelik arama faaliyetlerine daha fazla zaman ayırdıkları söylenebilmektedir. Hoffman ve Novak (1996, s. 65), bilgisayar aracılı ortamların olumsuz ağızdan ağıza iletişimi teşvik etme eğilimi sebebiyle, pazarlamacıların olumlu arama davranışlarını destekleyici bazı önlemler almalarının bu çerçevede önemli olduğunu savunmaktadır. Ayrıca, akış deneyiminin kullanıcı üzerindeki zaman baskısını azalttığı ve kullanıcıların ilgili eyleme ayırdıkları süreyi arttırdığı düşünüldüğünde olumlu bilgi kaynaklarının aranmasına yönelik daha fazla zaman ayrılmalarına katk1 sağlamaktadır. Diğer taraftan belirli bir geri bildirim faaliyeti için ayrılan zaman da dolayısıyla artmaktadır (Hoffman ve Novak, 1996, s. 61). Zaman algisındaki bozulmaya benzer bir diğer değişiklik mekân hissinde de yaşanabilmektedir. Heeter (1992, s. 263) bir bireyin fiziksel olarak olayın gerçekleştiği yerden uzakta olmasına rağmen kendisini olayın gerçekleştiği yerde hissetmesi tele varoluş kavramı ile tanımlamaktadır. Siber uzay davranışları ile akış deneyimi arasında yakın bir ilişsi bulunmasından (Chen, Wigand ve Nilan, 2000, s. 274; Novak vd., 2000, s. 24) yola çıkılarak, Heeter (1992, s. 262) tele varoluşun anlık optimal akış sonucu ortaya çıktığını öne sürmektedir. Akış durumu zaman ve mekâna bağlı olmasının yansıra son derece öznel bir olgudur. Bu sebeple, bir eylemin gerçekleştirilmesi esnasında akış durumunu deneyimleyen bazı bireyler o eyleme yönelik tekrarlama eğilimi geliştirebileceği düşünülmektedir (Csikszentmihalyi, 1990, s. 132; Chen vd., 2000, s. 264).

\section{Akış Deneyimi ve Bağımlılık}

Çevrim içi oyun bağımlllı̆̆, çevrim içi oyun oynamaya yönelik psikolojik bağlllık olarak ele alınmaktadır (Young, 1998; Ko vd., 2012). Bir kez bağımlılık geliştiğinde çevrim içi oyun oynayan oyuncular uzunca bir süre belirli bir oyunla meşgul olma eğilimi göstermektedir. Bireyin bir ürünün bazı zararlı yan etkileri bulunduğunu bilmesine karşın o ürünün tüketiminden elde edeceği zevk ve lezzet sebebiyle ürünün sahip olduğu potansiyel zararlı ve yan etkilerini göz ardı ederek, ürüne yönelik dayanılmaz bir tüketim isteğine sahip olan tüketiciler olarak tanımlanmakta (Chesney ve Hazari, 1998, s. 1) ve bu davranışları nedeniyle irrasyonel tüketiciler olarak nitelendirilmektedirler. Bu görüş çerçevesinde, pratik bir faydası olup olmadığına bakmaksızın bazı lezzet ve hazları takip edip onları tükettiğimiz 
düşünüldüğünde, bir dereceye kadar her tüketicinin irrasyonel birer tüketici olduğundan bahsedilebilmektedir (Chou ve Ting, 2003, s. 663). Fakat, Becker ve Murphy'nin (1988) bağımlllk davranışlarının açıklanabilmesine yönelik olarak öne sürmüş oldukları rasyonel bağımlılık teorisi çerçevesinde konuya farklı bir bakış açısı getirilmektedir. Bu teori kapsamında bağımlılıkların rasyonel olmadığı görüşünün aksine bağımlılık davranışlarının rasyonel olabileceği savunulmaktır. Teoriye göre, rasyonel tüketicilerin yaptıkları tercihler ile faydayı maksimize etmeye çalıştıkları gibi rasyonel olmadığı düşünülen, bağımlı müşterilerin de aslında maksimum fayda arayışında oldukları ve rasyonel davranışlar sergiledikleri öne sürülmektedir.

Bilgi teknolojileri ortamlarının incelenmesine yönelik gerçekleștirilen araştırmalar kapsamında optimal akış deneyiminin genel olarak olumlu çıktılara sahip olduğu değerlendirilmektedir (Hoffman ve Novak, 1996, s. 59; Koufaris, 2002, s. 213; Esteban vd., 2014, s. 112). Ancak akış deneyimi bazı olumsuz sonuçlara da yol açabilmektedir. Akış deneyimi insanların belirli bir davranışı tekrarlamalarını teşvik eden faktörler arasında yer almaktadır (Novak vd., 2000, s. 39). Diğer taraftan ise alışkanlıklar tekrarlı tüketici davranışları olarak ele alınmakta ve bağımlılığın en küçük belirtisi olarak değerlendirilmektedir. Bağımlilığı olan bir birey ile yalnızca alışkanlıkları tarafından yönlendirilen bir birey dışardan incelendiğinde, birbirinden açıkça ayırt edilebilmesi oldukça güçtür. Alıskanlık ve bağımlılık kavramlarının birbirlerine yakın kavramlar olması nedeniyle, bu iki kavramın zaman zaman birbirlerinin yerine de kullanıldığı görülmektedir (Chou ve Ting, 2003, s. 663). Temel olarak tüketim kararları tüketici tercihlerinin bir fonksiyonu olarak ele alındığında, davranışların tekrarlanması belirli bir noktadan sonra tüketici tercihlerinin yerini alabilmekte bu ise tüketimlerin alışkanlıklara dönüşmesine neden olabilmektedir (Wan, 2014, s. 90). Tüketimin kompulsif bir alışkanlık halini alması halinde, bireyin tekrarlı olarak seçmiş olduğu ürün ve hizmet dışındaki tüm seçeneklerin tercih edilme ihtimali ortadan kalkmış olmaktadır. Bu durumda, tercihler tüketiciler tarafindan verilen tüketim kararlarını açıklayabilmede yalnızca belli bir yere kadar yardımcı olabilmekte, geriye kalan kısımların ise alışkanlıklar ile ilgili olduğu düşünülmektedir. Bu noktada, tüketici davranışları önemli bir rol oynamaktadır fakat alışkanlıkların şekillenmesi sürecine yönelik bu alandaki bilginin nispeten sınırlı olduğu düşünülmektedir (Chou ve Ting, 2003, s. 663). Bu değerlendirmeler çerçevesinde, akış deneyimi bireylerin tekrarlı davranışlara ve dolayısıyla bilgi teknolojileri ürünlerinin kullanımına yönelik patolojik bir bağlllık oluşturmasına neden olabilmekte, böylelikle kötü bir alışkanlığın gelişmesini kolaylaştırabilmektedir (Chou ve Ting, 2003; Turel vd., 2011, s. 1054). Akış teorisi alanında gerçekleştirilen araştırmalar, bireyin bir eylemi gerçekleştirirken kendisini bu eyleme kaptırması durumunda tekrar etme eğilimi geliştireceği, bunun ise nihai olarak bağımlılı̆̆a yönelik bir eylemin gerçekleşmesine neden olacağıdır. Chou ve Ting (2003) siber oyunları oynarken akışı deneyimleyen oyuncuların bağımlı olma olasılıklarının yüksek olduğunu öne sürmektedir. Hsu, Wen ve Wu (2009, s. 997) ve Park ve Hwang (2009, s. 384) ise yapmıs oldukları araşıtımalarda akış deneyiminin, bağımlılık davranışının gelişimini olumlu yönde etkilediğini ifade etmektedirler. Diğer taraftan, Wan ve Chiou'nin (2006, s. 322) gerçekleştirmiş oldukları araştırma sonuçlarına göre ise kısa dönemde çevrim içi oyunlardaki akış durumu ile çevrim içi oyun bağımlılı̆̆ eğilimi arasında ters yönlü ilişki bulunduğu sonucuna ulaşılmış ve buna ek olarak akış deneyimi ile müşteri bağlllı̆̆1 arasında olumlu yönde bir ilişki olabileceğini ortaya koymuşlardır.

\section{Akış Deneyimi ve Ağızdan Ağıza Pazarlama}

Günümüz dünyasında oyun oynamak yalnızca belirli bir yaş grubuna ait bir aktivite olarak değerlendirilmemektedir (Wood, Griffiths, Chappell ve Davies, 2004, s. 1). Oyunlar günlük yaşamımızın vazgeçilmez parçası haline gelmiş ve işletmeler açısından da stratejik önemi gün geçtikçe daha da artmaktadır. Fakat diğer taraftan çevrim içi oyunlara yönelik ağızdan ağıza pazarlama faaliyetlerini etkileyen faktörler hakkında sahip olunan bilginin kısıtlı olduğu da anlaşılmaktadır (Huang vd., 2017, s. 329). Bu sebeple kullanıcıların çevrim içi oyunlara yönelik bağlılık dereceleri ile ağızdan ağıza pazarlama arasındaki ilişskinin açıklanmasına yönelik gerçekleştirilen çalışmaların arttırılmasına ihtiyaç olduğu düşünülmektedir (Liu, 2017, s. 155).

Pazarlama ve reklamcılık alanlarında gerçekleştirilen çalışmalarda ağızdan ağıza pazarlamanın tüketici karar verme sürecini etkilemedeki rolü vurgulanmaktadır (Gilly, Graham, Wolfinbarger ve Yale, 1998). Ağızdan ağıza pazarlama, tüketiciler arasında pazarlama bilgisinin alışverişi olarak tanımlanmakta ve ürün ve hizmetlere yönelik tüketici tutum ve davranışlarının değiştirilmesinde önemli bir rol oynamaktadır (Katz ve Lazarsfeld, 1955). Tüketiciler tarafindan ağızdan ağıza pazarlama faaliyetlerinin, ürünler ve markalar hakkında işletmeler tarafindan oluşturulan ikna edici mesajlardan daha güvenilir olduğunun kabul edilmesi sebebiyle (Feick ve Price, 1987, s. 94), tüketiciler satın alma kararlarını genellikle bu kanaldan gelen 
bilgilere dayandırmaktadırlar. Bununla birlikte elektronik haberleşme teknolojilerinin hızlı gelişimi ve bu teknolojilere erişimin kolaylaşması ağızdan ağıza pazarlama faaliyetlerinin önemini arttırmıştır. $\mathrm{Bu}$ kapsamda internet üzerinde gerçekleştirilen elektronik ağızdan ağıza pazarlama faaliyetleri, internet üzerinden çok sayıda kişi ve kurumun erişebileceği, bir ürün veya hizmet hakkında potansiyel, gerçek veya tüketiciler tarafindan gerçekleştirilen olumlu veya olumsuz ifade olarak tanımlanmaktadır (Hennig, Gwinner, Walsh ve Gremler, 2004, s. 39). Anlaşılacağ1 üzere günümüz gelişmeleri kapsamında ele alındığında, ağızdan ağıza pazarlama faaliyetleri bloglar, elektronik postalar, tüketiciler tarafindan içerik sağlanan inceleme siteleri veya forumları, sanal tüketici toplulukları ve sosyal ağ sistemleri gibi platformlar üzerinden gerçekleştirilebilmektedir (Chu ve Kim, 2011, s. 48).

Diğer bir husus ise uzman oyuncuların deneyimsiz oyunculara göre akış deneyiminden zevk alma ve oyun bağımlılı̆̆1 belirtileri gösterme olasıllğı daha yüksektir (Wu vd., 2013). Akışın deneyimlenmesi neticesinde, oyuncular oyun oynarken olumlu deneyimlere sahip olmakta ve sürekli çevrim içi oyun oynama eğilimi göstermektedirler (Choi ve Kim, 2004). Becker ve Murphy (1988) ve diğer ekonomistler tarafindan öne sürülen rasyonel bağımlılık teorisinde bağımlılı̆ın gelişimine yönelik olarak bazı detaylı bilgiler içermektedir. Bu kapsamda gerçekleştirilen araştırmalarda bireyin belirli ürünlerle sürekli etkileşimi zaman içerisinde tüketim sermayesini oluşturmaktadır. Bu sermaye zaman içerisinde arttıkça ürünün tüketiciye olan faydası artmakta bu ise bağımlılık olasılığının artmasına neden olmaktadır. Fakat yüksek faydaya sahip belirli ürünlere bağımlılık, ona bağlı olanların büyük bir mutluluk duyduğu anlamına gelmemektedir. Aksine bu bireyler isteklerinin mahkûmu olduğu değerlendirilmektedir, çünkü ürünü bulamadıklarında mutluluk seviyeleri düşme eğilimi göstermektedir (Chou ve Ting, 2003, s. 664).

Aşırı internet kullanımı uyuşturucu veya alkol bağımlılığına benzer sonuçlara neden olabilmektedir. İnternet bağımlllı̆ı sosyal ve davranışsal bozukluklara neden olabilmektedir (Kuss vd., 2014, s. 21). İnternet bağımlılı̆̆ının neden olduğu en sık karşılaşılan davranışlar, depresyon, düşmanlık ve siber zorbalık olarak sıralanabilmektedir (Chang vd., 2015, s. 26). Yen, Ko, Yen, Wu ve Yang (2007) agresif davranışların internet bağımlılığı ile ilişkili olduğunu, Ko, Yen, Liu, Huang, ve Yen (2009) ise internet bağımlilı̆ı olan ergen bireylerin saldırgan davranışlar gösterme olasılı̆̆ının diğer bireylere kıyasla daha fazla olduğunu savunmaktadırlar. Tüm bu çalışmalar internet bağımlılı̆̆ ile saldırganlık arasındaki güçlü ilişkiyi ortaya koymaktadır. Fakat bazı araştırmalarda bu ilişkinin nedensel bir ilişki olmadığını, aslında saldırgan davranış eğilimi olan bireylerin internet bağımlılı̆̆ geliştirebildiklerini savunmaktadır (Ko, Yen, Chen, Yeh, ve Yen, 2009). Milani, Osualdella ve Blasio (2009) sorunlu internet kullanımının kişilerarası ilişkileri de olumsuz yönde etkilediği sonucuna ulaşmışlardır. Çevrim içi anlık mesajlaşma uygulamalarına yönelik bağımlılık geliştiren bireylerin ailelerinden, akranlarından ve yakın sosyal çevresinden yabancılaştı̆̆ı görülmüştür. Israeli vd. (2019a, s. 155) tarafindan gerçekleştirilen bir araştırmada internet bağımlılı̆̆ının saldırgan müşteri davranışlarına neden olduğu bunun ise ağızdan ağıza pazarlama faaliyetlerine olumsuz yansıyabileceği ortaya konulmuştur. Bu sebeple bağımlı bireyler hizmet hatalarından kaynaklı sonuçlarla karşılaştıklarında ağızdan ağıza pazarlama faaliyetlerinde kötü söz kullanma eğilimi göstermektedirler (Israeli vd., 2019b, s. 958). Cavazos, Krauss, Sowles ve Bierut (2015, s. 635) tarafindan gerçekleştirilen araştırmaya göre ise bağımlılık davranışı gösteren bireyler bağımlı oldukları objelere yönelik bilgileri sosyal medya aracıllğı ile diğer bireyler ile paylaşmakta ve bu davranışların birer savunucusu olabilmektedirler.

\section{Metodoloji}

\section{Araştırmanın Amacı}

Araştırmanın amacı Akış Teorisi (Flow Theory) unsurlarının (eğlence, tele varoluş, konsantrasyon ve zaman algısında bozulma) mobil oyun oynayan bireylerin mobil oyun bağımlılıkları ve keşifsel davranışları üzerindeki etkilerinin belirlenmesi ve aynı zamanda da bu bireylerin mobil oyun bağımlılıklarının ve keşifsel davranışlarının pozitif ve negatif WOM faktörleri üzerindeki etkilerinin değerlendirilmesidir.

\section{Araştırmanın Modeli ve Hipotezleri}

Araştırmanın amacına uygun şekilde oluşturulan modelde akış teorisi unsurları olan konsantrasyon, eğlence, tele varoluş ve zaman algısında bozulma, mobil oyun bağımlılı̆̆ı, keşifsel davranış ve pozitif ve negatif WOM değişkenleri yer almaktadır. Araştırma modelinde yer alan değişkenler ve bu değişkenler arasındaki ilişki ilgili literatür incelenerek oluşturulmuştur. Araştırma modeli Şekil 1'de gösterilmektedir. İncelenen literatür çerçevesinde oluşturulan araştırma hipotezleri aşağıdaki gibidir; 
H1a: Eğlence keşifsel çevrim içi oyun davranışını pozitif yönde etkilemektedir.

H1b: Eğlence çevrim içi oyun bağımlılığı davranışını pozitif yönde etkilemektedir.

H2a: Konsantrasyon çevrim içi oyun keşifsel davranışını pozitif yönde etkilemektedir.

H2b: Konsantrasyon çevrim içi oyun bağımlılığı davranışını pozitif yönde etkilemektedir.

H3a: Zaman algısında bozulma keşifsel çevrim içi oyun davranışını pozitif yönde etkilemektedir.

H3b: Zaman algısında bozulma çevrim içi oyun bağımlılığı davranışını pozitif yönde etkilemektedir.

H4a: Tele varoluş keşifsel çevrim içi oyun davranışını pozitif yönde etkilemektedir.

H4b: Tele varoluş çevrim içi oyun bağımlllığ davranışını pozitif yönde etkilemektedir.

H5a: Çevrim içi oyun bağımlılı̆̆ı davranışı olumlu ağızdan ağıza pazarlamayı pozitif yönde etkilemektedir.

H5b: Çevrim içi oyun bağımlılı̆̆ davranışı olumsuz ağızdan ağıza pazarlamayı pozitif yönde etkilemektedir.

H6a: Keşifsel çevrim içi oyun davranışı olumlu ağızdan ağıza pazarlamayı pozitif yönde etkilemektedir.

H6b: Keşifsel çevrim içi oyun davranışı olumsuz ağızdan ağıza pazarlamayı pozitif yönde etkilemektedir.

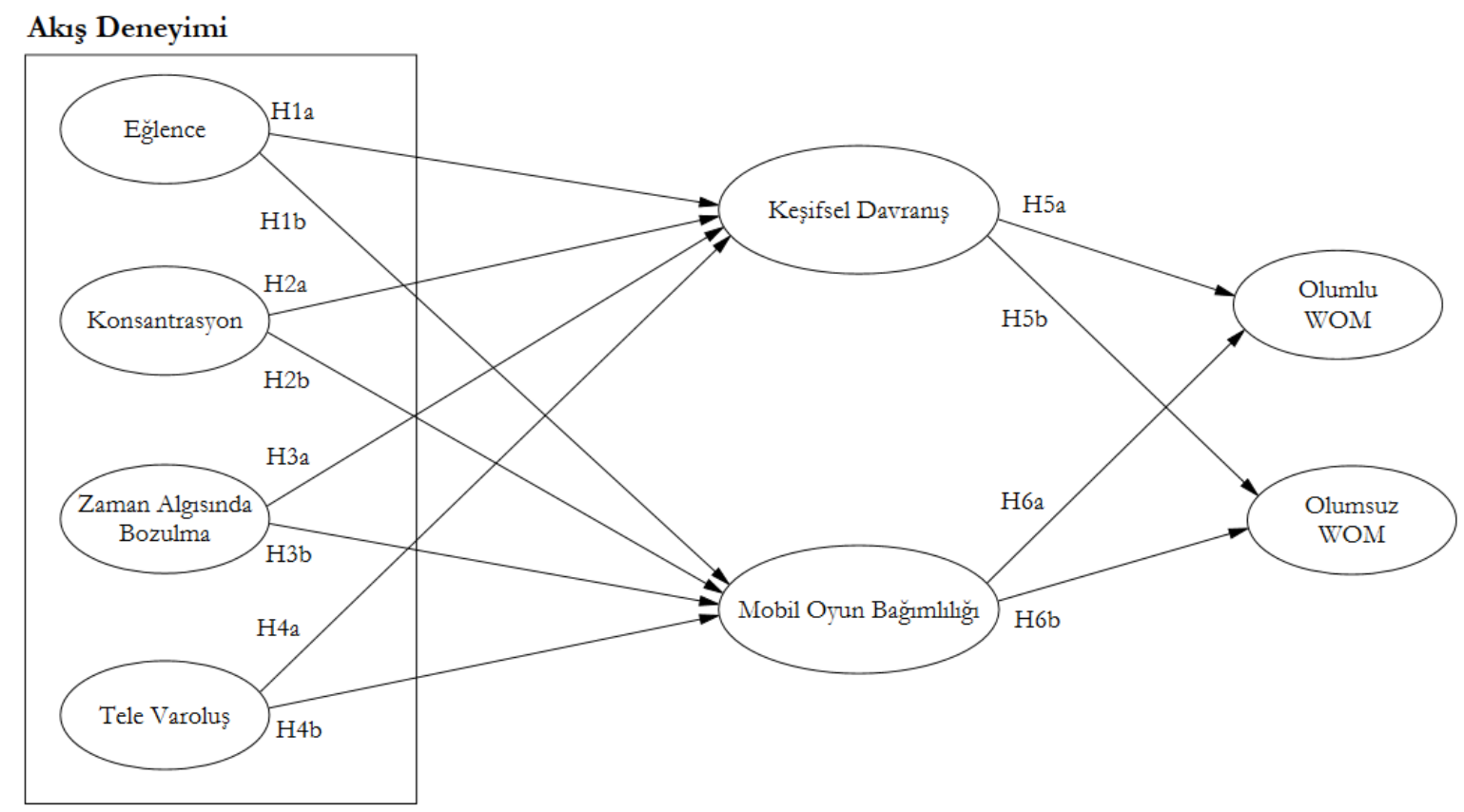

Şekil 1. Araştrma Modeli

\section{Araştırmanın Ana Kütlesi, Örneklem ve Verilerin Toplanması}

Araştırma evreni 18 yaşından büyük mobil oyun oynayan kişilerdir. Ana kütle içinde yer alan unsurların sayısına ait net bir bilgi olmadığında, tesadüfi olmayan örnekleme yöntemlerinden kolayda örnekleme tercih edilebilmektedir (Robson, 2002, s. 48). Araştırmamızda da örnekleme yöntemi olarak kolayda örnekleme kullanılmıştır. Araştırmanın ve araştırmada kullanılacak veri ile uygulanacak yöntemin etik değerlere uygun olduğuna dair karar Uşak Üniversitesi Sosyal ve Beşerî Bilimler Bilimsel Araştırma ve Yayın etiği Kurulu'nun 13.04.2020 tarih ve E.12886 sayll yazısıyla bildirilmiştir. Veri toplama amaciyla hazırlanan bu kapsamda hazırlanan anket formu, oluşturulan çevrimiçi form aracılı̆̆ ile elektronik posta ve öğrenci bilgi sistemi üzerinden Uşak Üniversitesi'nin farklı bölümlerindeki öğrencilere ve idari ve akademik personele 10 günlük sürede uygulanmış ve toplam 407 adet katılımcıdan veri sağlanabilmiştir. Ana kütlenin 100.000’ den büyük olduğu durumlarda 0,05 anlamllık düzeyinde elde edilen bu örneklem büyüklüğü yapısal eşitlik modellemesi için yeterlidir (Altunışık, Çoşkun, Bayraktaroğlu ve Yıldırım, 2005). Beşli likert (1-Kesinlikle Katılıyorum, 5-Kesinlikle Katılmıyorum) kullanılan veri seti, yapısal eşitlik modeli kullanılarak analiz edilmiştir. Araştırma modeli kapsamında öne sürülen araştırma değişkenlerinden akış deneyiminin ölçümlenmesine yönelik olarak dört boyut; eğlence 6 ifade (Novak vd., 2000; Hsu ve Chiu, 2004), konsantrasyon 5 ifade (Novak vd., 2000; Koufaris, 2002), zaman algisinda bozulma 3 ifade (Novak vd., 2000; Koufaris, 2002) ve tele varoluş 3 ifade (Novak vd., 2000; Koufaris, 2002) ilgili çalışmalardan 
uyarlanmıştır. Araştırmada kullanılan diğer ölçekler; mobil oyun bağımlılı̆ının ölçümüne yönelik 8 ifade (Young, 1998), keşifsel davranışa yönelik 5 ifade (Novak vd., 2000), olumlu ağızdan ağıza pazarlama 4 ve olumsuz ağızdan ağıza pazarlama yönelik 2 ifade (Goyette, Ricard, Bergeron ve Marticotte, 2010) ilgili çalısmalarından uyarlanarak araştırmaya dahil edilmiştir.

\section{Araştırmanın Bulguları}

\section{Tanımlayıcı İstatistiki Bulgular}

Katıllımciların cinsiyet, yaş, eğitim düzeyi ve gelir durumuna ait bulgular Tablo 1'de gösterilmektedir. Araştırmanın örnek kütlesini oluşturan katılımcıların yaklaşık \%43,9’u kadın ve \%56,1'i erkeklerden oluşmaktadır. Katılımcıların \%74,9’u 18-30 yaş sınırı aralığındadır. Ayrıca, 239 kişinin lisans, 32 kişinin ise yüksek lisans mezunu olduğu anlaşılmaktadır. Araştırmaya katılım sağlayan bireylerin gelir düzeylerine bakıldığında \%71,5'inin asgari ücret ve altında, \%10,5'inin ise 4901 TL ve üzerinde gelire sahip olduğu görülmektedir.

Tablo 1. Kathlimclarm Demografik Özellikleri

\begin{tabular}{llcc}
\hline Demografik Özellikler & & Frekans & $\%$ \\
\hline \multirow{2}{*}{ Cinsiyet } & Kadın & 179 & 43,9 \\
& Erkek & 228 & 56,1 \\
\hline \multirow{3}{*}{ Yaş } & $18-30$ & 305 & 74,9 \\
& $31-44$ & 76 & 18,6 \\
& 45 ve üzeri & 26 & 6,5 \\
\hline \multirow{4}{*}{ Eğitim Düzeyi } & İlköğretim & 16 & 3,9 \\
& Lise & 45 & 11,0 \\
& Ön lisans & 75 & 18,4 \\
& Lisans & 239 & 58,7 \\
Aylik Gelir Düzeyi & Lisansüstü & 32 & 8,0 \\
& 2324 TL ve alt1 & 291 & 71,5 \\
& $2325-3500$ TL & 32 & 8,0 \\
\hline & $3501-4900$ TL & 41 & 10,0 \\
\hline
\end{tabular}

\section{Yorumlayıcı İstatistiki Bulgular}

\section{Açımlayıcı Faktör Analizi (AFA) Bulgulanı}

AFA, değişken gruplarının faktörlerle ilişki düzeyini sınamak için kullanılan çok değişkenli bir analiz yöntemidir. Açımlayıcı faktör analizi sonuçları Tablo 2'de sunulmaktadır.

Tablo 2. Açmlayzu Faktör Analizi Sonucu

\begin{tabular}{|c|c|c|c|c|c|}
\hline Değişkenler & Ortalama & S. Sapma & Faktör Yükü & Özdeğer & $\alpha$ \\
\hline \multicolumn{6}{|l|}{ Eğlence } \\
\hline EG1 & 3,98 & 0,772 & 0,745 & \multirow{6}{*}{7,227} & \multirow{6}{*}{0,861} \\
\hline EG2 & 3,94 & 0,850 & 0,780 & & \\
\hline EG3 & 3,99 & 0,797 & 0,793 & & \\
\hline EG4 & 4,01 & 0,815 & 0,756 & & \\
\hline EG5 & 3,99 & 0,864 & 0,760 & & \\
\hline EG6 & 3,96 & 0,847 & 0,730 & & \\
\hline \multicolumn{6}{|l|}{ Konsantrasyon } \\
\hline KON1 & 3,68 & 0,905 & 0,829 & \multirow{5}{*}{3,831} & \multirow{5}{*}{0,871} \\
\hline KON2 & 3,71 & 0,899 & 0,827 & & \\
\hline KON3 & 3,74 & 0,854 & 0,774 & & \\
\hline KON4 & 3,70 & 0,824 & 0,788 & & \\
\hline KON5 & 3,70 & 0,879 & 0,745 & & \\
\hline \multicolumn{6}{|l|}{ Tele Varoluş } \\
\hline TV1 & 3,45 & 0,861 & 0,778 & \multirow{3}{*}{1,464} & \multirow{3}{*}{0,894} \\
\hline TV2 & 3,45 & 0,826 & 0,821 & & \\
\hline TV3 & 3,51 & 0,952 & 0,874 & & \\
\hline \multicolumn{6}{|c|}{ Zaman Algısında Bozulma } \\
\hline ZAB1 & 3,49 & 0,871 & 0,834 & \multirow{3}{*}{2,328} & \multirow{3}{*}{0,876} \\
\hline ZAB2 & 3,47 & 0,832 & 0,855 & & \\
\hline ZAB3 & 3,40 & 0,887 & 0,826 & & \\
\hline
\end{tabular}




\begin{tabular}{|c|c|c|c|c|c|}
\hline Değişkenler & Ortalama & S. Sapma & Faktör Yükü & $\ddot{O} z d e \breve{g} e r$ & $\alpha$ \\
\hline \multicolumn{6}{|l|}{ Mobil Oyun Bağımlılı̆̆1 } \\
\hline MOB1 & 3,78 & 0,832 & 0,745 & \multirow{8}{*}{3,225} & \multirow{8}{*}{0,889} \\
\hline MOB2 & 3,79 & 0,749 & 0,752 & & \\
\hline MOB3 & 3,63 & 0,840 & 0,716 & & \\
\hline MOB4 & 3,66 & 0,850 & 0,717 & & \\
\hline MOB5 & 3,63 & 0,777 & 0,722 & & \\
\hline MOB6 & 3,72 & 0,880 & 0,755 & & \\
\hline MOB7 & 3,67 & 0,846 & 0,712 & & \\
\hline MOB8 & 3,68 & 0,869 & 0,758 & & \\
\hline \multicolumn{6}{|l|}{ Keşifsel Davranış } \\
\hline KD1 & 3,71 & 0,880 & 0,757 & \multirow{5}{*}{2,814} & \multirow{5}{*}{0,840} \\
\hline KD2 & 3,58 & 0,897 & 0,716 & & \\
\hline KD3 & 3,56 & 0,846 & 0,761 & & \\
\hline KD4 & 3,58 & 0,925 & 0,744 & & \\
\hline KD5 & 3,53 & 0,865 & 0,707 & & \\
\hline \multicolumn{6}{|l|}{ Olumlu WOM } \\
\hline PW1 & 3,45 & 0,823 & 0,745 & \multirow{4}{*}{1,872} & \multirow{4}{*}{0,842} \\
\hline PW2 & 3,43 & 0,824 & 0,797 & & \\
\hline PW3 & 3,39 & 0,847 & 0,817 & & \\
\hline PW4 & 3,40 & 0,830 & 0,812 & & \\
\hline \multicolumn{6}{|l|}{ Olumsuz WOM } \\
\hline NW1 & 3,10 & 0,821 & 0,915 & \multirow{2}{*}{1,576} & \multirow{2}{*}{0,852} \\
\hline NW2 & 3,04 & 0,862 & 0,908 & & \\
\hline \multicolumn{6}{|l|}{ KMO Testi: 0,851} \\
\hline Barlett Sphericity Testi: 7 & $: 0,000$ & & & & \\
\hline
\end{tabular}

Bu kapsamda araştırma modelinde yer alan eğlence faktörüne ait 6 madde, konsantrasyon faktörüne ait 5 madde, tele varoluş faktörüne ait 3 madde, zaman algısında bozulma faktörüne ait 3 madde, mobil oyun bağımlılı̆g faktörüne ait 8 madde, keşifsel davranış faktörüne ait 5 madde, olumlu WOM faktörüne ait 4 madde ve olumsuz WOM faktörüne ait 2 madde olmak üzere toplam 38 madde için faktör analizi yapilmıştır. Tablo 2'ye göre, araştırma modelinde yer alan faktörlerin KMO değeri \%0,851 ve Barlett's Sphericity testi değeri $\mathrm{p}<0,001$ 'dir. Faktör analizindeki değerlere bakıldığında, soru formundaki tüm önermelerin puanlarının kabul edilebilir sınırlar içerisinde olduğu görülmektedir. Elde edilen verilere bakıldığında; tüm faktörlere ait yüklerin ise 0,70 üzerinde değerlerde olduğu anlaşılmaktadır.

\section{Doğrulayıcı Faktör Analizi (DFA) Bulguları}

Açımlayıcı faktör analizinden sonra, araştırma modelinin güvenirliğini ve geçerliliğini sınayabilmek için DFA kullanılmıştır. DFA, araştırma çerçevesinde sağlanan verilerle teorik olarak oluşturulan yapının doğruluğunu analiz edilebilmek için uygulanmaktadır (Çokluk, Şekercioğlu ve Büyüköztürk, 2016, s. 177). Tablo 3'te DFA sonucunda ortaya çıkan değerler sunulmaktadır.

Tablo 3. Doğrulayzc Faktör Analiz̨i Sonuclar

\begin{tabular}{|c|c|c|c|c|c|}
\hline Değişkenler & $S E Y K$ & $t$ değeri & $C R$ & $A V E$ & $M S V$ \\
\hline \multicolumn{6}{|l|}{$\overline{\text { Eğlence }}$} \\
\hline EG1 & 0,707 & 12,418 & \multirow{6}{*}{0,861} & \multirow{6}{*}{0,508} & \multirow{6}{*}{0,064} \\
\hline EG2 & 0,747 & 13,582 & & & \\
\hline EG3 & 0,738 & 13,580 & & & \\
\hline EG4 & 0,724 & 13,213 & & & \\
\hline EG5 & 0,711 & & & & \\
\hline EG6 & 0,708 & 12,254 & & & \\
\hline \multicolumn{6}{|c|}{ Konsantrasyon } \\
\hline KON1 & 0,780 & 15,441 & \multirow{5}{*}{0,871} & \multirow{5}{*}{0,576} & \multirow{5}{*}{0,130} \\
\hline KON2 & 0,778 & 15,403 & & & \\
\hline KON3 & 0,751 & 14,840 & & & \\
\hline KON4 & 0,761 & & & & \\
\hline KON5 & 0,722 & 14,243 & & & \\
\hline \multicolumn{6}{|l|}{ Tele Varoluş } \\
\hline TV1 & 0,835 & 20,429 & \multirow{3}{*}{0,895} & \multirow{3}{*}{0,739} & \multirow{3}{*}{0,174} \\
\hline TV2 & 0,872 & 21,475 & & & \\
\hline TV3 & 0,871 & & & & \\
\hline \multicolumn{6}{|c|}{ Zaman Algisında Bozulma } \\
\hline ZAB1 & 0,847 & 18,367 & 0,877 & 0,704 & 0,251 \\
\hline
\end{tabular}


ŞAHIN ve KARAHAN

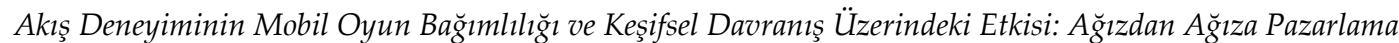

Kapsaminda Bir İncelenme

\begin{tabular}{|c|c|c|c|c|c|}
\hline Değiskenler & $S E Y K$ & tdeğeri & $C R$ & $A V E$ & $M S V$ \\
\hline ZAB2 & 0,857 & 18,529 & & & \\
\hline ZAB3 & 0,812 & & & & \\
\hline \multicolumn{6}{|c|}{ Mobil Oyun Bağımlılı̆̆1 } \\
\hline MOB1 & 0,768 & 13,092 & \multirow{8}{*}{0,840} & \multirow{8}{*}{0,512} & \multirow{8}{*}{0,261} \\
\hline MOB2 & 0,726 & 12,377 & & & \\
\hline MOB3 & 0,717 & 12,117 & & & \\
\hline MOB4 & 0,702 & & & & \\
\hline MOB5 & 0,703 & 11,914 & & & \\
\hline MOB6 & 0,733 & 12,614 & & & \\
\hline MOB7 & 0,701 & 11,589 & & & \\
\hline MOB8 & 0,744 & 12,770 & & & \\
\hline \multicolumn{6}{|c|}{ Keşifsel Davranış } \\
\hline KD1 & 0,709 & 12,068 & \multirow{5}{*}{0,889} & \multirow{5}{*}{0,501} & \multirow{5}{*}{0,116} \\
\hline KD2 & 0,742 & 13,733 & & & \\
\hline KD3 & 0,745 & 13,774 & & & \\
\hline KD4 & 0,732 & & & & \\
\hline KD5 & 0,706 & 13,104 & & & \\
\hline \multicolumn{6}{|l|}{ Pozitif WOM } \\
\hline PW1 & 0,701 & 13,464 & \multirow{4}{*}{0,843} & \multirow{4}{*}{0,575} & \multirow{4}{*}{0,174} \\
\hline PW2 & 0,742 & 14,517 & & & \\
\hline PW3 & 0,775 & & & & \\
\hline PW4 & 0,819 & 15,872 & & & \\
\hline \multicolumn{6}{|l|}{ Negatif WOM } \\
\hline NW1 & 0,789 & & \multirow{2}{*}{0,859} & \multirow{2}{*}{0,754} & \multirow{2}{*}{0,032} \\
\hline NW2 & 0,941 & 5,568 & & & \\
\hline
\end{tabular}

Modelin geçerliliği ile ilgili kıstaslara bakıldığında SEYK ve CR değerlerinin 0,70 değerinden büyük, AVE değerinin de 0,50 'den büyük ve son olarak MSV değerinin AVE değerinden küçük ve AVE'nin karekökünün faktörler arası korelasyondan büyük olduğu görülmektedir. DFA gerçekleştirildikten sonra $t$ değerlerinin anlamlılık düzeylerinin 2,56 değerinden büyük olduğu da kontrol edilmiştir. Tablo 3'te elde edilen $\mathrm{t}$ değerlerinin 0,01 düzeyinde anlamlı olduğu ifade edilebilir. AFA'da olduğu gibi DFA'da da soru formundaki tüm önermelerin puanlarının kabul edilebilir sınırlarda olduğu ifade edilebilir.

Ayırt edici geçerliliğin doğrulanması amacıyla değişkenler arasındaki ilişkiyi sembolize eden korelasyon matrisi ve AVE değerlerinin karekökleri hesaplanarak Tablo 4'te gösterilmiştir. AVE karekökünün boyutlar arası en yüksek korelasyon değerinden büyük olduğu anlaşılmaktadır.

Tablo 4. Korelasyon Katsaynlar ve AVE Karekök Değerleri

\begin{tabular}{llcccccccc}
\hline & & $\mathbf{1}$ & $\mathbf{2}$ & $\mathbf{3}$ & $\mathbf{4}$ & $\mathbf{5}$ & $\mathbf{6}$ & $\mathbf{7}$ & $\mathbf{8}$ \\
\hline 1 & Negatif WOM & $\mathbf{0 , 8 7}$ & & & & & & & \\
2 & Ĕglence & 0,03 & $\mathbf{0 , 7 1}$ & & & & & & \\
3 & Konsantrasyon & 0,13 & 0,08 & $\mathbf{0 , 7 6}$ & & & & & \\
4 & Mobil Oyun Bağılmlılı̆̆1 & 0,18 & 0,17 & $\mathbf{0 , 3 6}$ & $\mathbf{0 , 7 2}$ & & & & \\
5 & Keşifsel Davranış & 0,08 & 0,25 & 0,25 & 0,34 & $\mathbf{0 , 7 1}$ & & & \\
6 & Zaman Algısında Bozulma & 0,10 & 0,10 & 0,15 & 0,24 & 0,50 & $\mathbf{0 , 8 4}$ & & \\
7 & Pozitif WOM & 0,18 & 0,06 & 0,06 & 0,07 & 0,35 & 0,36 & $\mathbf{0 , 7 6}$ & \\
8 & Tele Varoluş & 0,01 & 0,07 & 0,19 & 0,23 & 0,26 & 0,27 & 0,42 & $\mathbf{0 , 8 6}$ \\
\hline
\end{tabular}

Not: AVE karekökleri köșegen (diagonal) ve koyu olarak verilmiștir.

Doğrulayıcı faktör analizine ilişkin olarak ölçme modelinin uyum iyiliği değerlerine de bakılmıştır. Tablo 5’te doğrulayıcı faktör analizi uyum iyiliği değerleri gösterilmektedir.

Tablo 5. DF A Uyum İiliğ̈ Değerleri Sonucu

\begin{tabular}{lcc}
\hline Uyum Indeksi & DFA Sonucu Elde Edilen Değer & Sonuc \\
\hline$\chi^{2} / \mathrm{df}$ & 1,92 & Mükemmel Uyum \\
\hline RMSEA & 0,05 & Mükemmel Uyum \\
\hline CFI & 0,93 & Kabul Edilebilir Uyum \\
\hline SRMR & 0,04 & Mükemmel Uyum \\
\hline PClose & 0,82 & Mükemmel Uyum
\end{tabular}




\section{Yapısal Analiz ve Hipotez Testi Sonuçlan}

Yapısal analiz işleminin gerçekleştirilmesi ile, araştırma modeli doğrulanarak hipotezler test edilmiştir. Analiz sonucuna göre, araştırma modelinin uyum iyiliği değerlerinin kabul edilebilir ölçülerde olduğu Tablo 6'da gösterilmektedir.

Tablo 6. Yapısal Model Uyum İyiliğ̈ Değerleri

\begin{tabular}{lcc}
\hline Uyum Indeksi & YEM Sonucu Elde Edilen Değer & Sonuç \\
\hline$\chi^{2} / \mathrm{df}$ & 1,96 & Mükemmel Uyum \\
\hline RMSEA & 0,05 & Mükemmel Uyum \\
\hline CFI & 0,92 & Kabul Edilebilir Uyum \\
\hline SRMR & 0,06 & Mükemmel Uyum \\
\hline PClose & 0,71 & Mükemmel Uyum \\
\hline Kaynak: Kline (2011)
\end{tabular}

Kaynak: Kline (2011)

Tablo 7'de araştırma hipotezlerinin test edilmelerini sağlayan ve araştırma modelinde yer alan faktörler arasındaki ilişkileri ortaya koyan bulgular gösterilmektedir.

Tablo 7. Yol Analizi Sonuclar ve Hipotęler

\begin{tabular}{|c|c|c|c|}
\hline Hipotezler & Standardize Edilmis Yol Katsay1sı & tdeğeri & $P$ \\
\hline H1a: Eğlence $\rightarrow$ Keşifsel Dav. & 0,24 & 4,22 & $* * *$ \\
\hline H1b: Eğlence $\rightarrow$ Oyun Bağ. & 0,15 & 2,71 & 007 \\
\hline H2a: Konsantrasyon $\rightarrow$ Keşifsel Dav. & 0,27 & 4,87 & *** \\
\hline H2b: Konsantrasyon $\rightarrow$ Oyun Bağ. & 0,35 & 5,92 & *** \\
\hline H3a: Zaman alg1s1 $\rightarrow$ Keşifsel Dav. & 0,09 & 1,72 & 0,09 \\
\hline H3b: Zaman alg1s1 $\rightarrow$ Oyun Bağ. & 0,49 & 8,14 & *** \\
\hline H4a: Tele Varoluş $\rightarrow$ Keşifsel Dav. & 0,16 & 2,94 & *** \\
\hline H4b: Tele Varoluş $\rightarrow$ Oyun Bağ. & 0,23 & 3,94 & $* * *$ \\
\hline H5a: Keşifsel Dav. $\rightarrow$ Olumlu WOM & 0,04 & 0,76 & 0,44 \\
\hline H5b: Keşifsel Dav. $\rightarrow$ Olumsuz WOM & 0,03 & 0,50 & 0,62 \\
\hline H6a: Oyun Bağ. $\rightarrow$ Olumlu WOM & 0,38 & 6,09 & $* * *$ \\
\hline H6b: Oyun Bağ. $\rightarrow$ Olumsuz WOM & 0,18 & 2,74 & 006 \\
\hline
\end{tabular}

${ }^{* * *} p<0,001$ düreyinde anlamle

Tablo 7'de yer alan araştırmanın varsayımlarının test edildiği yol analizi bulgularına göre; H1a, H1b, H2a, H2b, H3b, H4a, H4b, H6a ve H6b hipotezleri kabul edilmiştir. Araştırmada elde edilen sonuçlara göre, akış teorisi unsurlarının (eğlence, konsantrasyon, zaman algisı ve tele varoluş) tamamı bireylerin mobil oyun bağımlılığı ve yine zaman alg1sı faktörü hariç tüm akış teorisi unsurları keşifsel davranış üzerinde $\mathrm{p}<0,01$ düzeyinde anlamlı etkiye sahiptir. Ayrıca, keşifsel davranış faktörünün aksine mobil oyun bağımlllı̆̆ının olumlu ve olumsuz WOM faktörleri üzerinde anlamlı bir etkisinin olduğu görülmektedir.

\section{Sonuçlar}

Çalışma, eğlencenin bireylerin mobil oyun bağımlılı̆̆ ve keşifsel davranış üzerinde olumlu ve anlamlı bir etkiye sahip olduğu göstermektedir. C. L. Hsu ve Lu (2004) çevrim içi oyunların adoptasyonu ve daha sonra bağımlılık haline gelme sürecinde, Sun, Zhao, Jia, ve Zheng (2015) mobil oyun bağımlıllğında, Chou ve Ting (2003) sanal oyun bağımlılığında Akış Teorisi’nden yararlandıkları çalışmalarında eğlencenin mobil oyun bağımlılığı noktasında en önemli unsurlardan birisi olduğunu belirtmişlerdir. Bireylerin akış süreci içerisindeki durumları son derece öznel olmasına rağmen, yaptıkları faaliyetleri eğlenceli bulmaları, bu faaliyetleri sıklıkla tekrar etme eğiliminde bulunmalarına neden olmaktadır. Rasyonel Bağımlılık Teorisi de tekrar edilen eylemler dizisinin bağımlılığa dönüşebileceğinden bahsetmektedir (Webster vd., 1993). Ghani ve Ghani ve Deshpande (1994) ve Novak vd. (2000) internet kullanımı bağımlılı̆ını Akış Teorisi kullanarak ele aldıkları çalışmalarında, kullanıcıların keşifsel davranışta bulunmasına neden olan faktörün merak duygusu olduğunu belirtmekle birlikte, çalışmamıza paralel şekilde eğlence faktörünün keşifsel davranış üzerinde anlamlı bir etkiye sahip olduğunu belirtmişlerdir. Konsantrasyon faktöründe olduğu gibi eğlence faktörününde de mobil oyunların bağımlılık seviyesinde popüler olmaları ve bireylerin merak duygularının ortaya çıkmasını sağlamaları açısından önemli olduğu açıkça görülmektedir

Araștırma sonucunda Akış Teorisi unsurlarından olan konsantrasyonun mobil oyun bağımlıllı̆̆ ve keşifsel davranış üzerinde pozitif ve anlamlı bir etkisinin olduğu ifade edilebilir. Yang vd. (2014), internet bağımlılığına etki eden faktörleri inceledikleri çalısmalarında Akış Teorisi unsurlarından konsantrasyon faktörünün bağımlılık ve keşifsel davranış üzerindeki anlamlı etkisinden bahsetmişlerdir. Sanjamsai ve 
Phukao (2018), bilgisayar oyun bağımlılı̆̆ını inceledikleri araştırmalarında konsantrasyon faktörünü duygusal akış sürecinin bir unsuru olarak isimlendirmiş ve bağımllıkla anlamlı ilişkisinden bahsetmiştir. Akış deneyimi yaşayan bireylerin, mobil oyun oynarken konsantrasyon seviyelerinin mümkün olan en üst seviyede olması, oyuna bağlanmaları ve daha da fazlasını isteyerek yeni şeyler keşfetmeleri için tetikleyici rol oynamaktadır.

Akış teorisi unsurlarından yalnızca zaman algısında bozulmanın, mobil oyun bağımlılığı üzerinde anlamlı bir etkiye sahip olduğu; keşifsel davranış üzerinde ise anlamlı bir etkiye sahip olmadığı sonucuna ulaşılmışır. Bu sonuç bireylerin patolojik ve patolojik olmayan davranışları arasındaki farkı yansıtması açısından önemlidir. Hoffman ve Novak (1996, s. 65) araştırmanın sonucuna paralel şekilde, zaman algısından uzaklaşan bireylerin bağımlılık düzeylerinin arttı̆̆ını belirtmişlerdir.

Tele varoluş faktörü, internet ve oyun bağımlllığı literatürde yer alan çalışmaların çoğunda (Park ve Hwang, 2009; Stavropoulos, Alexandraki, ve Motti-Stefanidi, 2013; Liu ve Chang, 2016) olduğu gibi yapılan araştırmada da oyun bağımlılığı ve keşifsel davranış üzerinde anlamlı etkiye sahiptir.

Keşifsel çevrim içi oyun davranışının olumlu ve olumsuz ağızdan ağıza pazarlamayı anlamlı düzeyde etkilemediği görülmektedir. Bireylerin keşifsel davranış sergilerken, bağımlıllk düzeyinde olduğu kadar zaman harcamamaları, kendilerine ayırdıkları zamanı özel ve anlamlı hissedebilmeleri ve dolayısıyla her zaman kendilerine ait hissettikleri duyguları ve keşiflerini paylaşmamaları, araştırma hipotezinin reddedilmesi sonucunu doğurmuş olabilmektedir.

Araştırmada mobil oyun bağımlılı̆ının olumlu ve olumsuz WOM üzerinde anlamlı bir etkisinin olduğu görülmektedir. Liu ve Chang (2016), bilgisayar bazlı iletişim ve çevrim içi oyun ilişkisini inceledikleri araştırmalarında, bağımlılık düzeyinde çevrim içi oyun oynayan bireylerin referans gruplarıyla oyunlar hakkında konuşmak, sosyal mecralarda oyunla ilgili beğeni ya da etkileşimde bulunarak sosyalleşmeye çalıstıklarını belirtmişlerdir.

Oyunlar günümüz dünyasının önemli bir parçası haline gelmiş ve oyun oynamak tüm yaş gruplarının ortak paydası olarak değerlendirilmektedir. Ulaşılan sonuçlar çerçevesinde değerlendirildiğinde oyun tasarımcıları ve oyunlaştırma uygulamalarını kullanacak olan işletmelerin bazı hususlara dikkat etmeleri gerekmektedir. Oyunlar tüm gelir, yaş ve cinsiyet grupları arasında yaygınlaşması sebebiyle oyun tasarımcılarının ve oyunlaştırma faaliyetlerini kullanan işletmelerin bu hususları birincil olarak göz önünde bulundurmalidırlar.

Tüketicilerin kendi aralarında gerçekleştirdikleri ağızdan ağıza iletişim faaliyetleri işletmeler tarafından gerçekleştirilen iletişim faaliyetlerinden daha etkili olduğu kabul edilmektedir. Bu kapsamda ele aldığımızda oyun bağımlısı bireylerin ağızdan ağıza pazarlama faaliyetlerinde bulunma davranışlarının daha baskın bir yapıya sahip olması işletmeler açısından olumlu sonuçları olabileceği gibi aynı zamanda bazı olumsuz neticelere de neden olabilmektedir. Bunun temel nedeni bağımlılık davranışı sergileyen bireylerin genel olarak agresif bir tutum içerisinde bulunmalarından kaynaklanmaktadır. Bu olumsuzlukların azaltılabilmesi amacıyla oyun tasarımında eğlence unsurunun arttırlarak kullanıcıların keşifsel davranışlar sergilemesi arttırılabileceği ve böylelikle oyun ve oyunlaştırma kapsamında gönderilen mesajın daha etkin bir şekilde ulaşabilmesi sağlanabilecektir. Diğer taraftan zaman baskısının azaltılması bağımlılık davranışı sergileyen kullanıcıların olumsuz ağızdan ağıza iletişim faaliyetlerinin sınırlandırılmasında önemli bir oynayabileceği değerlendirilmektedir. Zaman algısında bozulma ve tele varoluş faktörlerinin bağımllık davranışı üzerindeki etkisinin keşifsel davranışlara kıyasla daha fazla olduğu değerlendirildiğinden kullanıcılara verilecek oyun içi etkinliklerini tamamlamak için verilen sürenin sürekli bir yapıdan daha çok kesikli bir yapıya sahip olmasının bu etkileri azaltabileceği değerlendirilmektedir. Örneğin verilen bir görevin tamamlanmasında kullanıcıların kaldığı yerden devam edebilmelerinin sağlanması gibi bir uygulama bu konuda etkili olabilecektir. Bu şekilde tasarlanan oyun ve oyunlaştırma uygulamaları sayesinde oyuncuların akış içerisinde kendi zaman algıları ve tele varoluş durumlarını yönetebilme serbestliği sağlanabileceği değerlendirilmektedir. Pazarlama kapsamında ele alındığında ağızdan ağıza pazarlama iletişiminde veya işletme içerisindeki farklı amaçlar kapsamında oyunlaşturma uygulamaları ile başlı başına bir ürün olarak oyunu ele alındığında uygulamalara yönelik bağımlılık sergileyen bireylerin gerçekleştirebileceği olumlu veya olumsuz ağızdan ağıza etkileşimin önemi göz önünde bulundurulmalıdır. Bu açıdan bağımlılık davranışı sergileyen bireylere yönelik özel iletişim kanallarının açık tutulması bazı olumsuzlukların önceden engellenebilmesinde önemli olduğu değerlendirilmektedir. Özet olarak oyun ve oyunlaştırma uygulamalarının tasarımında kullanıcıların akış durumumda etkili olan eğlence, konsantrasyon, zaman algısı ve tele varoluş faktörlerinin birbirleri arasında etkileşim içinde olduğu ve bunların her birisinin olumlu ve 
olumsuz davranışlara neden olabileceği göz önünde bulundurularak en optimum şekilde bir araya getirilmesi gerekmektedir.

\section{Araştırmanın Sınırlılıkları ve Öneriler}

Araştırma kapsamında kolayda örnekleme yöntemi kullanılarak verilerin elde edilmesi; araştırma örneklem sayısı ve örneklemi oluşturan unsurlar istatistiksel açıdan tesadüfi olmayan yollarla belirlendiği için sonuçların genellenmesi güçleştirmektedir. Ayrıca, örnek kütlenin sayısının zaman ve maliyet gibi etkenler nedeniyle sınırlı kalması da bir diğer kısıttır.

Mobil oyun tasarlayan yazılım uzmanlarının, bireylerin konsantrasyon seviyelerini maksimum kılacak şekilde oyun tasarlamaları ve pazarlama uzmanlarının da mobil oyunların promosyonu sürecinde konsantrasyon faktörünün üzerinde durmalarının gerekliliği araştırmanın önemli çıkarımlarındandır. Ayrıca, keşifsel davranış sergileyen bireylerin daha fazla sayıda oyun indirmeleri, oynadıkları oyunları da paylaşmalarının daha olası olduğu dikkate alınmalıdır. Elbette ki, konsantrasyon faktörünün de akış deneyim süreci içerisinde oyun içeriğine bağlı olarak amaca uygunluk, bireylerin algısal, bilişsel bilgi ve becerileriyle uyumu, dikkat çekici uyarıcıya sahip olması gibi özelliklerin de göz önünde bulundurulması gerekmektedir (Sweetser ve Wyeth, 2005).

Bireylerin oyun esnasında etkileşimde bulunabilmeleri, kendilerini oyuna kaptırabilmeleri için duyusal gerçeklik hissedebilmeleri ve merak duygusuyla farklı rollere bürünebilmeleri, oyun bağımlılı̆ı ve keşifsel davranış faktörlerini olumlu etkileyecektir. Dolayısıyla, pazarlama uzmanlarının ve oyun yazılımcılarının bu etkenlere dikkat etmesi gerekmektedir.

Araştırmada, mobil oyun bağımlılığına sahip bireylerin oyunla kurdukları bağa ve o anki hislerine göre olumlu ya da olumsuz ağızdan ağıza iletişime geçebildikleri görülmektedir. Ağızdan ağıza iletişimin, bireylerin referans grupları arasında gerçekleşmesi ve dolayısıyla da daha samimi ve gerçekçi olarak değerlendirildiği göz önüne alınırsa, mobil oyunların kalite unsurlarının (hız, boyut, bağlantı, etkileşim vb.) bireyleri tatmin edecek şekilde düzenlenmesi ve tasarlanması gerektiği anlaşılmaktadır.

Gelecekte yapılacak araştırmalarda, kullanıcıların cinsiyeti, gelir grubu, yaşadıkları şehir gibi demografik faktörleri göz önünde bulundurularak mobil oyun bağımllıkları ve keşifsel davranışlar karşılaştırılabilir. Fokus grupları ile belirlenen spesifik oyun türleri seçilerek kullanıcıların belirlenen bu farklı türdeki (macera, aksiyon, puzzle vb.) mobil oyunlara olan yaklaşımları farklı sosyal psikoloji teorileri (Rasyonel Teori, Planlı Davranış Teorisi vb.) kullanılarak belirlenebilir.

\section{Etik Beyan}

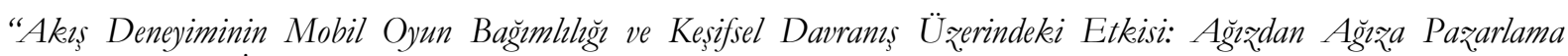
Kapsamında Bir Incelenme” başlıklı çalışmanın yazım sürecinde bilimsel kurallara, etik ve alıntı kurallarına uyulmuş; toplanan veriler üzerinde herhangi bir tahrifat yapılmamış ve bu çalışma herhangi başka bir akademik yayın ortamına değerlendirme için gönderilmemiştir. Gerekli olan etik kurul izinleri Uşak Üniversitesi Sosyal ve Beşeri Bilimler Bilimsel Araştırma ve Yayın Etiği Kurulu'nun 13.04.2020 tarih ve 2020-42 saylı toplantısında alınmıstır.

\section{Kaynakça}

Altunışık, R., Çoşkun, R., Bayraktaroğlu, S. ve Yıldırım, E. (2005). Sosyal bilimlerde araştırma yöntemleri SPSS uygulamalı (4. Bask1). Sakarya: Sakarya Kitabevi.

Becker, G. S., ve Murphy, K. M. (1988). A theory of rational addiction. Journal of Political Economy, 96(4), 675-700.

Cavazos-Rehg, P. A., Krauss, M. J., Sowles, S. J. ve Bierut, L. J. (2015). “Hey everyone, I'm drunk." An evaluation of drinking-related Twitter chatter. Journal of Studies on Alcohol and Drugs, 76(4), 635-643.

Chang, F. C., Chiu, C. H., Miao, N. F., Chen, P. H., Lee, C. M., Chiang, J. T. ve Pan, Y. C. (2015). The relationship between parental mediation and internet addiction among adolescents, and the association with cyberbullying and depression. Comprehensive Psychiatry, 57, 21-28.

Chen, H., Wigand, R. T. ve Nilan, M. (2000). Exploring web users' optimal flow experiences. Information Technology \& People, 13(4), 263-281.

Chen, J. (2007). Flow in games (and everything else). Communications of the ACM, 50(4), 31-34.

Chesney, M. ve Hazari, B. (1998). Irrational entry, rational exit. Journal of Mathematical Economics, 29(1), 1-13.

Cheung, C. M. ve Thadani, D. R. (2012). The impact of electronic word-of-mouth communication: A literature analysis and integrative model. Decision Support Systems, 54(1), 461-470. 
Choi, D. ve Kim, J. (2004). Why people continue to play online games: in search of critical design factors to increase customer loyalty to online contents. Cyberpsychology \& Behavior, 7(1), 11-24.

Chou, T. J. ve Ting, C.-C. (2003). The role of flow experience in cyber-game addiction. Cyberpsychology \& Behavior, 6(6), 663-675.

Chu, S. C. ve Kim, Y. (2011). Determinants of consumer engagement in electronic word-of-mouth (e-wom) in social networking sites. International Journal of Advertising, 30(1), 47-75.

Conaway, R. ve Garay, M. C. (2014). Gamification and service marketing. Springer Plus, 3(1), 653.

Consalvo, M. (2006). Console video games and global corporations: creating a hybrid culture. New Media \& Society, $8(1), 117-137$.

Csikszentmihalyi, M. (1975). Beyond boredom and anxiety: the experience of play in work and leisure. In. San Francisco, CA: Jossey-Bass.

Csikszentmihalyi, M. (1990). Flow: the psychology of optimal experience (Vol. 1990). New York: Harper \& Row.

Çokluk, Ö., Şekercioğlu, G. ve Büyüköztürk, Ş. (2016). Sosyal bilimler için çok değişsenli istatistik: SPSS ve Lisrel uygulamaları (4. Baskı). Ankara: Pegem Akademi Yayınları.

Esteban Millat, I., Martínez-López, F. J., Huertas-García, R., Meseguer, A. ve Rodríguez-Ardura, I. (2014). Modelling students' flow experiences in an online learning environment. Computers \& Education, 71, 111-123.

Feick, L. F. ve Price, L. L. (1987). The market maven: a diffuser of marketplace information. Journal of Marketing, 51(1), 83-97.

File, S. E. (1985). What can be learned from the effects of benzodiazepines on exploratory behavior? Neuroscience \& Biobehavioral Reviews, 9(1), 45-54.

Ghani, J. A. ve Deshpande, S. P. (1994). Task characteristics and the experience of optimal flow in human-computer interaction. The Journal of Psychology, 128(4), 381-391.

Gilly, M. C., Graham, J. L., Wolfinbarger, M. F. ve Yale, L. J. (1998). A dyadic study of interpersonal information search. Journal of The Academy of Marketing Science, 26(2), 83-100.

Godes, D. ve Mayzlin, D. (2004). Using online conversations to study word-of-mouth communication. Marketing Science, 23(4), 545-560.

Goyette, I., Ricard, L., Bergeron, J. ve Marticotte, F. (2010). E-wom scale: word-of-mouth measurement scale for eservices context. Canadian Journal of Administrative Sciences, 27(1), 5-23.

Guo, Y. M. ve Poole, M. S. (2009). Antecedents of flow in online shopping: a test of alternative models. Information Systems Journal, 19(4), 369-390.

Hauser, J. R., Urban, G. L. ve Weinberg, B. D. (1993). How consumers allocate their time when searching for information. Journal of Marketing Research, 30(4), 452-466.

Hausman, A. V. ve Siekpe, J. S. (2008). The effect of web interface features on consumer online purchase intentions. Journal of Business Research, 62(1), 5-13.

Heeter, C. (1992). Being there: The subjective experience of presence. Presence: Teleoperators \& Virtual Environments, 1(2), 262-271.

Hennig-Thurau, T., Gwinner, K. P., Walsh, G. ve Gremler, D. D. (2004). Electronic word-of-mouth via consumeropinion platforms: what motivates consumers to articulate themselves on the internet? Journal of Interactive Marketing, 18(1), 38-52.

Hofacker, C. F., De Ruyter, K., Lurie, N. H., Manchanda, P. ve Donaldson, J. (2016). Gamification and mobile marketing effectiveness. Journal of Interactive Marketing, 34, 25-36.

Hoffman, D. L. ve Novak, T. P. (1996). Marketing in hypermedia computer-mediated environments: conceptual foundations. Journal of Marketing, 60(3), 50-68.

Hoffman, D. L. ve Novak, T. P. (2009). Flow online: lessons learned and future prospects. Journal of Interactive Marketing, 23(1), 23-34.

Hsu, C. L. ve Lu, H. P. (2004). Why do people play on-line games? An extended tam with social influences and flow experience. Information \& Management, 41(7), 853-868.

Hsu, M. H. ve Chiu, C. M. (2004). Internet self-efficacy and electronic service acceptance. Decision Support Systems, 38(3), 369-381.

Hsu, S. H., Wen, M. H. ve Wu, M. C. (2009). Exploring user experiences as predictors of MMORPG addiction. Computers \& Education, 53(3), 990-999.

Huang, M., Ali, R. ve Liao, J. (2017). The effect of user experience in online games on word of mouth: a pleasurearousal-dominance (pad) model perspective. Computers in Human Behavior, 75(2017), 329-338.

Huotari, K. ve Hamari, J. (2017). A definition for gamification: anchoring gamification in the service marketing literature. Electronic Markets, 27(1), 21-31.

Israeli, A. A., Lee, S. A. ve Bolden III, E. C. (2019a). The impact of escalating service failures and internet addiction behavior on young and older customers' negative e-wom. Journal of Hospitality and Tourism Management, (39), 150157.

Israeli, A. A., Lee, S. A. ve Karpinski, A. C. (2019b). The relationship between internet addiction and negative ewom. The Service Industries Journal, 39(13-14), 943-965.

Jiang, Z. ve Benbasat, I. (2004). Virtual product experience: effects of visual and functional control of products on perceived diagnosticity and flow in electronic shopping. Journal of Management Information Systems, 21(3), 111-147. 
Kardefelt Winther, D. (2014). A conceptual and methodological critique of internet addiction research: towards a model of compensatory internet use. Computers in Human Behavior, 31(2014), 351-354.

Katz, E. ve Lazarsfeld, P. F. (1955). Personal influence, the part played by people in the flow of mass communications. New York: Free Press.

Kim, E. J., Namkoong, K., Ku, T. ve Kim, S. J. (2008). The relationship between online game addiction and aggression, self-control, and narcissistic personality traits. European Psychiatry, 23(3), 212-218.

Kim, Y. Y., Oh, S. ve Lee, H. (2005). What makes people experience flow? Social characteristics of online games. International Journal of Advanced Media and Communication, 1(1), 76-92.

Kurcaburun, K., Demetrovics, Z. ve Tosuntaş, Ş. B. (2019). Analyzing the links between problematic social media use, dark triad traits, and self-esteem. International Journal of Mental Health and Addiction, 17(6), 1496-1507.

Kline, R. B. (2011). Principles and practice of structural equation modeling (3rd ed.). London: Guilford Publications.

Ko, C. H., Yen, J. Y., Chen, C. S., Yeh, Y. C. ve Yen, C. F. (2009a). Predictive values of psychiatric symptoms for internet addiction in adolescents: a 2-year prospective study. Archives of Pediatrics \& Adolescent Medicine, 163(10), 937-943.

Ko, C. H., Yen, J. Y., Liu, S. C., Huang, C. F., ve Yen, C. F. (2009b). The associations between aggressive behaviors and internet addiction and online activities in adolescents. Journal of Adolescent Health, 44(6), 598-605.

Ko, C. H., Yen, J. Y., Yen, C. F., Chen, C. S., ve Chen, C. C. (2012). The association between internet addiction and psychiatric disorder: a review of the literature. European Psychiatry, 27(1), 1-8.

Koufaris, M. (2002). Applying the technology acceptance model and flow theory to online consumer behavior. Information Systems Research, 13(2), 205-223.

Kuss, D. J. ve Griffiths, M. D. (2012). Internet gaming addiction: a systematic review of empirical research. International Journal of Mental Health and Addiction, 10(2), 278-296.

Kuss, D. J., Griffiths, M. D., Karila, L. ve Billieux, J. (2014). Internet addiction: a systematic review of epidemiological research for the last decade. Current Pharmacentical Design, 20(25), 4026-4052.

Landsman, V. ve Stremersch, S. (2011). Multihoming in two-sided markets: an empirical inquiry in the video game console industry. Journal of Marketing, 75(6), 39-54.

Lee, M. C. (2009). Understanding the behavioural intention to play online games. Online Information Review, 33(5), 849872.

Lee, S. M. ve Chen, L. (2010). The impact of flow on online consumer behavior. Journal of Computer Information Systems, 50(4), 1-10.

Lenhart, A., Kahne, J., Middaugh, E., Macgill, A. R., Evans, C. ve Vitak, J. (2008). Teens, video games, and civics: teens' gaming experiences are diverse and include significant social interaction and civic engagement. American Life Project, Washington, DC: Pew Internet.

Lin, C. Y., Hung, W. H., Fang, K. ve Tu, C. C. (2015). Understanding players' achievement values from MMORPGS: An exploratory study. Internet Research, 25(5), 829-851.

Liu, C. C. (2017). A model for exploring players flow experience in online games. Information Technology \& People, 30(1), 139-162.

Liu, C. C., ve Chang, I. C. (2016). Model of online game addiction: the role of computer-mediated communication motives. Telematics and Informatics, 33(4), 904-915.

Meyer, J. S. (1998). Behavioral assessment in developmental neurotoxicology: Approaches involving unconditioned behaviors pharmacologic challenges in rodents. In Slikker, W. \& Chang, L.W. (Eds.), Handbook of Developmental Neurotoxicology (pp. 403-426). San Diego: Academic Press.

Milani, L., Osualdella, D. ve Di Blasio, P. (2009). Quality of interpersonal relationships and problematic internet use in adolescence. Cyberpsychology \& Behavior, 12(6), 681-684.

Novak, T. P., Hoffman, D. L. ve Yung, Y.-F. (2000). Measuring the customer experience in online environments: a structural modeling approach. Marketing Science, 19(1), 22-42.

Park, S. ve Hwang, H. S. (2009). Understanding online game addiction: connection between presence and flow. In: Jacko J.A. (eds) Human-Computer Interaction: Interacting in Various Application Domains. HCI 2009. Lecture Notes in Computer Science, vol 5613. Berlin, Heidelberg: Springer. https://doi.org/10.1007/978-3-642-02583-9_42

Robson, C. (2002). Real world research: A resource for social scientists and practitioner-researchers. Oxford: Blackwell.

Sanjamsai, S. ve Phukao, D. (2018). Flow experience in computer game playing among Thai university students. Kasetsart Journal of Social Sciences, 39(2), 175-182.

Seah, M. L. ve Cairns, P. (2008). From immersion to addiction in videogames. People and Computers XXII Culture, Creativity, Interaction, 22(2008), 55-63.

Shaffer, H. J., LaPlante, D. A., LaBrie, R. A., Kidman, R. C., Donato, A. N. ve Stanton, M. V. (2004). Toward a syndrome model of addiction: multiple expressions, common etiology. Harvard Review of Psychiatry, 12(6), 367374.

Shin, J., Chae, H. ve Ko, E. (2018). The power of e-wom using the hashtag: focusing on SNS advertising of spa brands. International Journal of Advertising, 37(1), 71-85.

Statista. (2020a). Digital market outlook, video games: Turkey. Erişim adresi: https://www.statista.com/outlook/203/113/video-games/turkey. 


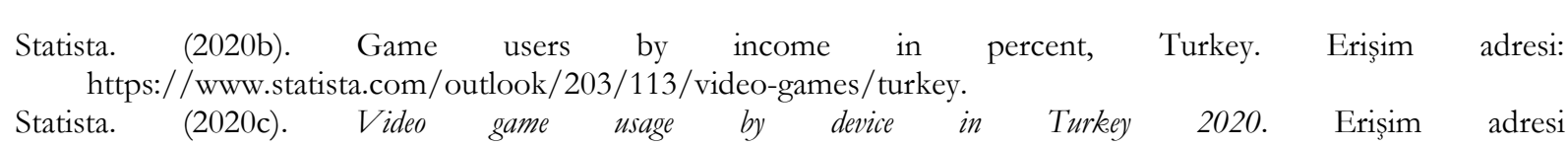
https://www.statista.com/forecasts/1003005/video-game-usage-by-device-in-turkey.

Stavropoulos, V., Alexandraki, K. ve Motti-Stefanidi, F. (2013). Recognizing internet addiction: prevalence and relationship to academic achievement in adolescents enrolled in urban and rural Greek high schools. Journal of adolescence, 36(3), 565-576.

Sun, Y., Zhao, Y., Jia, S. Q. ve Zheng, D.-Y. (2015). Understanding the antecedents of mobile game addiction: the roles of perceived visibility, perceived enjoyment, and flow. In proceeding of the 19th Pacific-Asia Conference on Information Systems (ss.1-12). Marian Bay Sands, Singapore.

Sweetser, P. ve Wyeth, P. (2005). Gameflow: a model for evaluating player enjoyment in games. Computers in Entertainment (CIE), 3(3), 3-3.

Turel, O., Serenko, A. ve Giles, P. (2011). Integrating technology addiction and use: an empirical investigation of online auction users. MIS quarterly, 1043-1061.

Wan, C. S. ve Chiou, W. B. (2006). Why are adolescents addicted to online gaming? An interview study in Taiwan. Cyberpsychology \& Behavior, 9(6), 762-766.

Wan, J. (2014). Consumer casualties: Exploring the economics of habit, information, and uncertainty in Japan, New York: Palgrave Macmillan.

Webster, J., Trevino, L. K. ve Ryan, L. (1993). The dimensionality and correlates of flow in human-computer interactions. Computers in Human Behavior, 9(4), 411-426.

Weibel, D., Wissmath, B., Habegger, S., Steiner, Y., ve Groner, R. (2008). Playing online games against computer-vs. Human-controlled opponents: effects on presence, flow, and enjoyment. Computers in Human Behavior, 24(5), 2274-2291.

Wood, R. T., ve Griffiths, M. D. (2007). Time loss whilst playing video games: is there a relationship to addictive behaviours? International Journal of Mental Health and Addiction, 5(2), 141-149.

Wood, R. T., Griffiths, M. D., Chappell, D. ve Davies, M. N. (2004). The structural characteristics of video games: a psycho-structural analysis. Cyberpsychology \& Behavior, 7(1), 1-10.

Wu, T.-C., Scott, D. ve Yang, C.-C. (2013). Advanced or addicted? Exploring the relationship of recreation specialization to flow experiences and online game addiction. Leisure Sciences, 35(3), 203-217.

Yang, S., Lu, Y., Wang, B. ve Zhao, L. (2014). The benefits and dangers of flow experience in high school students' internet usage: the role of parental support. Computers in Human Behavior, (41), 504-513.

Yen, J. Y., Ko, C. H., Yen, C. F., Wu, H. Y. ve Yang, M. J. (2007). The comorbid psychiatric symptoms of internet addiction: attention deficit and hyperactivity disorder (ADHD), depression, social phobia, and hostility. Journal of Adolescent Health, 41(1), 93-98.

Yen, W. C. ve Lin, H. H. (2020). Investigating the effect of flow experience on learning performance and entrepreneurial self-efficacy in a business simulation systems context. Interactive Learning Environments, 1-16.

Young, K. S. (1998). Internet addiction: the emergence of a new clinical disorder. Cyberpsychology \& Behavior, 1(3), 237-244.

Zaman, M., Anandarajan, M. ve Dai, Q. (2010). Experiencing flow with instant messaging and its facilitating role on creative behaviors. Computers in Human Behavior, 26(5), 1009-1018.

Zhou, T. (2013). The effect of flow experience on user adoption of mobile TV. Behaviour \& Information Technology, 32(3), 263-272.

Zhu, F. ve Zhang, X. (2010). Impact of online consumer reviews on sales: the moderating role of product and consumer characteristics. Journal of Marketing, 74(2), 133-148.

\section{EXTENDED ABSTRACT}

The context of marketing literature shows that managers thought that every newly coined concept has business opportunity possibilities for differentiation in the market. While some of these popular concepts cannot find the desired interest, the others found useful and have taken a permanent place in marketing practices. Online games and gamification are amongst the newly coined concepts with the emergence of new technology, and they found useful and applied in varying fields of marketing. The emergence of online games as an industry alone itself and prevalent interest by consumers towards these new forms of games drew marketing practitioners' attention to these improvements that lead them to think that to benefit from applying game elements into the marketing process called gamification. Nevertheless, while these practices provide some opportunities for marketing practitioners to gain a competitive advantage in creating customer value, they also have some hindrances. Usage related issues towards these practices can be problematic and cause unexpected outcomes. Related to increasing the popularity of internet usage by the public, the internet (Young, 1998) and online games (Kuss ve Griffiths, 2012) are assessed amongst the addictive activities by psychology literature. Because the addictive nature of the internet and online game applications cause alteration of consumer habits, so these reflect on behavior. Online games are thought to one of the most addictive behaviors on the internet by psychology 
literature (Lin vd.,2015: 844). The initial thought of this assumption is based on users' repetitive behaviors turn into habits. Researchers in this field assume that human-computer interaction playing an important role in building users' habits towards the internet and related application usage. Because this approach research that examine antecedents and consequences of human-computer interaction focus on users' flow experience. Flow experience assumes that when a user in the flow state, they concentrated on certain activities, which causes them to turn into a common experience. One of the early definitions of flow experience suggested by Csikszentmihalyi (1975), a situation in which the challenges related to a certain activity are paired by the person's perceived skills.

The aim of this study examines the role of addictive and exploratory behaviors on word of mouth in the context of flow experience. Considering the flow experience affects addictive and exploratory behavior to a certain extent that leads to the change of users' behavior toward certain activities. In this perspective, flow experience is measured respectively with four dimensions as enjoyment, concentration, telepresence and time distortion. The flow experience dimensions are assumed as antecedents of addictive and exploratory behaviors to examine the level of effect. Consequently, the effect of addictive and exploratory behaviors on negative WOM and positive WOM is examined. In the analysis of the research model structural equation modeling was employed by using SPSS and Amos software. The research findings show that enjoyment has a significant effect on exploratory $(\beta=0,24, t=4,22, p<0,001)$ and addictive behavior $(\beta=0,15, \mathrm{t}=2,71, \mathrm{p}<0,05)$. This finding also suggests that the increased enjoyment component of flow experience in game playing activity improves users' exploratory behavior. Additionally, concentration has significant effect on exploratory behavior $(\beta=0,27, t=4,87, p<0,001)$ and addictive behavior $(\beta=0,35, t=5,92, p<0,001)$. In comparison with two factors, concentration increases addictive behavior towards mobile games is slightly higher than exploratory behavior. Besides that, while the effect of time distortion on exploratory behavior is not supported $(\beta=0,09, t=1,72, p>0,05)$, results show that when the user's perception of time is distorted this will increase addictive behavior $(\beta=0,49, t=8,14$, $\mathrm{p}<0,001)$. The research assumptions on telepresence are supported. The effect of the telepresence component of flow experience shows a slight difference in exploratory $(\beta=0,16, t=2,94)$ and addictive behavior $(\beta=0,23, t=3,94)$. These findings show that when flow experience factor sorted by the effect on addictive behavior regarding their impact can be sorted as time distortion, concentration, and telepresence. In addition to those findings, the effect of exploratory behavior on positive and negative WOM is not supported, while addictive behavior affects both positive $(\beta=0,38, t=6,09)$ and negative $\operatorname{WOM}(\beta=0,18$, $\mathrm{t}=2,74)$. According to these findings, to managing relationships effectively with consumers who display addictive behavior towards playing games, game developers and marketing practitioners need to determine these consumers and prepare special marketing offers. The results show that consumers who have addictive behavior tend to provide positive information to other consumers as much as negative ones. Hence, the marketing practices, which prevent game players who have addictive behaviors to encounter negative experiences while emphasizing positive ones will increase their positive WOM tendency.

This research has several limitations; first the simple random sampling method employed in the data collection process makes it difficult to generalize the research results. The second limitation is sample size constrained with time, cost, etc. In future studies, users' exploratory and addictive behavior towards mobile games can be compared, considering demographic factors. In addition to that, environmental, consumer personality, and psychological factors, can be used in future research on mobile game addiction, contribute to the understanding of consumer addictive behavior, and marketing practices. 